IFN Working Paper No. 1028, 2014

\title{
Sensitivity to Shocks and Implicit Employment Protection in Family Firms
}

Carl Magnus Bjuggren 


\title{
Sensitivity to Shocks and Implicit Employment Protection in Family Firms*
}

\author{
Carl Magnus Bjuggren ${ }^{\dagger}$
}

June 8, 2014

\begin{abstract}
In this study I present empirical evidence that employment in family firms is less sensitive to performance and product market fluctuations, both at the industry and at the firm level. This supports the idea that family firms are able to offer their employees implicit employment protection. Family firms are believed to have longer time horizons, and are as owners more easily identified with their company and its actions. These are features that could make family firms more cautious in terms of adjusting their employment. I confirm previous findings that family firms are less sensitive to sales fluctuations at the industry level and I show that this also holds for fluctuations in value added. I extend the analysis to show that family firms are less sensitive to unanticipated industry shocks by filtering out the trend component. When investigating idiosyncratic shocks to the firm, I find that family firms are less anxious to translate temporary shocks in performance into changes in employment. By using full population data from tax registers, I am able to identify all family firms, both listed and non-listed. This has previously not been feasible.
\end{abstract}

Keywords: Family Firms, Risk Sharing, Employment Protection, Shocks

JEL classification: G32, J23, L25, D22, J21

*I am grateful for useful comments and suggestions from Sahaja Acharya, Ola Andersson, Per Hjertstrand, Dan Johansson, Matilda Orth, Hans Sjögren, Per Skedinger, Mikael Stenkula, and seminar participants at Stockholm School of Economics EHFF, CeFEO at Jönköping University, CESIS at KTH Royal Institute of Technology, and the Ratio Institute. I gratefully acknowledge financial support from the Jan Wallander and Tom Hedelius Research Foundation as well as from the Marianne and Marcus Wallenberg Foundation.

${ }^{\dagger}$ Research Institute of Industrial Economics (IFN), Box 55665, SE-102 15, Sweden.

Email: carl.magnus.bjuggren@ifn.se 


\section{Introduction}

In most countries, family firms constitute the majority of privately held firms and a significant part of publicly held firms (Bertrand \& Schoar 2006, Morck et al. 2005, La Porta et al. 1999, Bjuggren et al. 2011, Faccio \& Lang 2002, Astrachan \& Shanker 2003). Consequently, scholars are showing an increased interest in the performance and behavior of family firms in relation to firms with more dispersed ownership. Although the family firm literature is not very coherent, many studies seem to agree upon the idea that family firms have longer time horizons and are as owners and managers more easily identified with the company and its actions (see Anderson \& Reeb 2003, Chandler \& Hikino 1990, Landes 1949, Bandiera et al. 2011, Sraer \& Thesmar 2007, Block 2010). These are features that could affect the firm's employment decisions. Recent studies indicate that family firms are more cautious in their hiring and firing decisions (Sraer \& Thesmar 2007, Bassanini et al. 2013, D'Aurizio \& Romano 2013, Bach 2010).

The purpose of this study is to investigate how employment in family firms reacts to product market and performance fluctuations, both at the industry and at the firm level. The specific inquiry of family firms' sensitivity to shocks has previously been investigated by Sraer \& Thesmar (2007). Sraer \& Thesmar (2007) show that employment in heir-managed family firms is less sensitive to industry sales fluctuations. Their analysis is based on a sample of listed firms. One of the advantages with this study is that I have access to full population data in which I can identify all family firms. This has previously not been feasible. The first part of this study replicates and confirms some of the findings from the study by Sraer \& Thesmar (2007). I then extend the analysis to industry value added fluctuations and confirm that also in this case family firms are less sensitive.

When using industry sales or value added fluctuations one will capture movements that are due to both a trend component and a random component. That family firms are less sensitive to fluctuations at the industry level could therefore be a result of family firms following a different trend, or that they are less sensitive to unanticipated shocks, or both. To shed some light on this issue I filter out the trend component in a first stage regression on sales and value added, and use the remaining residual as a measure of unanticipated shocks at the industry level. My results indicate that family firms are less sensitive to these unanticipated shocks.

Using variation at the industry level could be deceptive if family firms are systematically less exposed to shocks. It is therefore interesting to investigate the response to idiosyncratic shocks to the firm. In order to investigate how family firms react when exposed to shocks at the individual firm level, I will follow the strategy proposed by Guiso et al. (2005) to 
separate the firm level shock into a permanent and a transitory component. A more recent adoption of this strategy include Cardoso \& Portela (2009) and Kátay (2008). ${ }^{1}$ My results indicate that family firms are less sensitive to temporary shocks in sales and value added.

An essential problem is to decide who shall bear the risk associated with exogenous fluctuations in production. Stiglitz (1987) argues that letting the worker bear the risk of these fluctuations is inefficient. If firms could ensure employees against exogenous shocks, they would be willing to work for much smaller salaries. If this takes the form of an implicit contract, there is however a commitment problem for the manager. There are too strong incentives to renegotiate such an implicit contract ex post. There is also the threat of a change of manager who does not have to honor previous contracts. Shleifer \& Summers (1988) discuss this problem and stress the importance of loyalty and long-term commitment. They argue that a person that spends a long time within a company before becoming a CEO will develop a commitment to the stakeholders. In particular, Shleifer \& Summers (1988) mention that the offspring of family firms could be raised with a certain loyalty towards all parties involved in the business. Hence, the loyalty and long-term commitment created by family managers could possibly solve the issue of trust and commitment.

The idea that family firms could be more able to commit to implicit contracts with their employees has been investigated empirically by Sraer \& Thesmar (2007) and by Bassanini et al. (2013). In addition there is a working paper by Bach \& Serrano-Velarde (2011), which addresses the same topic. All of these three studies are using data on French firms and find support for the idea that family firms are offering implicit employment insurance in return for lower wages. Moreover, the close tie between a family owner, or manager, and their company might for example be manifested in the company name. This makes them more easily sanctioned and monitored by society. The idea that family owners and managers are more responsible towards their employees is put forward by e.g. Dyer \& Whetten (2006), Stavrou et al. (2007), and Wiklund (2006). There is also a branch of literature that argues that family firms are guided to a large extent by altruistic incentives and act like stewards rather than agents (Miller \& Le Breton-Miller 2006).

The feature of risk aversion in family firms is often mentioned in the literature (see e.g.; Bandiera et al. 2011, Chandler \& Hikino 1990, Landes 1949, Morck 2000, Sraer \& Thesmar 2007), but the implications on employment adjustments have not been thoroughly discussed. In fact, risk averse firms, regardless of ownership, are shown to pursue a faster adjustment of employment back to steady state when hit by a sudden shock. Risk aversion serves as

\footnotetext{
${ }^{1}$ There is a conference paper by Ellul et al. (2013) that also investigate family firm's sensitivity to both temporary and permanent shocks. Their paper is inspired by Guiso et al. (2005) but they use a slightly different specification.
} 
a self-adjusting device in the sense that it steers the firm closer to the steady state level of profits, minimizing fluctuations (Choudhary \& Levine 2010). An interesting strand of literature within the field of business and management are challenging the notion of general risk aversion in family firms. The argument is based on the risk of losing what is called "socioemotional wealth", which refers to an emotional value on non-financial aspects of the firm. Socioemotional wealth includes for example the ability to exercise family influence as well as the preservation of the firm. The ability to exercise influence and the survival of the firm then becomes an end in itself. A family firm is believed to be more willing to accept for example below-target performance to avoid the loss of socioemotional wealth. Family firms are also believed to avoid venturing risk, which includes search for new technology and products (Gómez-Meja et al. 2007, Berrone et al. 2012). This is in line with the results that family firms appear to be less anxious to translate temporary shocks into employment adjustments at the same time as they do not seem to differ in their response to permanent shocks.

There are a small number of empirical studies that focus on the difference between family and non-family firms when it comes to employment adjustments. Bach (2010) shows that family firms show less volatile sales and employment growth paths. The two studies by Lee (2006) and Block (2010) investigate family firm behavior among listed firms in the US. Lee (2006) finds that family firm maintain relative employment stability during temporary market downturns, and Block (2010) finds that family firms are less likely to downsize when it comes to deep job cuts. Moreover, D'Aurizio \& Romano (2013) show that in the aftermath of the 2008 crisis, family firms chose to safeguard workplaces close to the firm's headquarters compared to other plants. Finally, the differentiation between listed and non-listed firms is likely important. Davis et al. (2007) finds that volatility in listed and non-listed firms follow different trends over time. Moreover, some of the features that are believed to be specific to family firms, such as long-term commitment, are features that can also be achieved by enlisting on the stock exchange. Listed firms also differ from the average firm when it comes to financing needs and growth perspectives.

The previous research on family firms has, with a few exceptions, been restricted to rather small samples or even case studies. This has resulted in most of the existing empirical evidence on the functions and behavior of family firms being somewhat less elaborated (Astrachan \& Shanker 2003, Shanker \& Astrachan 1996). The identification of family ownership has typically been made through investigating business reports, business press, or by educated guesses, interviews, or questionnaires. The time consuming nature of these identification procedures has inevitably excluded the majority of firms. The data I use are register based micro data on all Swedish firms from 1997-2009, in which I am able to identify all 
family firms in the economy, both listed and non-listed. ${ }^{2}$ The identification is made possible by a tax reform in the early 1990s that required the Swedish Tax Authority to identify family relations among ultimate owners of every Swedish firm.

By matching firm-level data with establishment data, I am able to locate firms according to municipality, and I am therefore able to control for geographical location. This has, to my knowledge, not been done before in this context. The geographical distribution in this study reveals that family firms are relatively less frequent in the big metropolitan areas. This skewed distribution indicates that the environment in which family firms operate is different on average. Taking the geographical distribution into account is most likely important for a better identification of the effect of family ownership.

I begin by describing the data and present some descriptive statistics on family firms. Section 3 investigates the sensitivity of employment to industry level shocks and section 4 investigates the different shock components at the firm level. Section 5 concludes the paper.

\section{Data}

The data used are register data from Statistics Sweden (SCB) on all firms with at least five employees, and covers the period from 1997 to 2009. For firms with less than 5 employees there is little variation in ownership concentration. The data are obtained from various register sources. Number of employees and geographical location is obtained from the RAMS-register (Labor Statistics Based on Administrative Sources), and Företagsdatabasen (Statistics Sweden's Business Register). Data on sales and value added are obtained from Företagens Ekonomi (the Structural Business Statistics), and deflated using the fixed consumer price index (CPI) from Statistics Sweden. Information on closely held firms is obtained from the Swedish Tax Authority, and information on family-owners in listed firms is obtained from the annual compilation "Owners and Power in Sweden's Listed Companies" by SvenIvan Sundqvist. Number of employees is defined according to the number of employees in November earning a salary that exceeds a certain threshold (RAMS 2006). ${ }^{3}$

\footnotetext{
${ }^{2}$ I will throughout this paper refer to publicly traded firms as listed, and private firms that do not offer to trade the company to the public, as non-listed.

${ }^{3}$ To determine the threshold, individuals are divided into 25 categories depending on variables such as age, gender, and retirement pension. As an example, in 2005, for a male of age 25-54, the threshold is an annual salary of 50036 SEK (Statistics Sweden 2008). This is equivalent of about USD 7 750, using the exchange rate in September 18, 2013.
} 


\section{Definition and identification of family firms}

There is little agreement on how to define a family firm. Practice ranges from more broad definitions, such as a firm in which a family is in control over the strategic decisions of the business, to more narrow definitions, such as a firm in which the founder and multiple generations are active and have declared the desire to keep the business within the family (Astrachan \& Shanker 2003). For example, the European Commission (2009) lists more than 90 definitions, most of which are not applicable to studies using large data sets. In this paper, I will apply the definition of a family firm as a firm in which a family or a single individual controls more than 50 percent of the ultimate voting rights. This definition is slightly stricter than the one used by e.g., La Porta et al. (1999) and Faccio \& Lang (2002) where a family or a single individual has to control more than 20 percent of the voting rights. ${ }^{4}$

An alternative to using concentrations of ultimate voting rights would be to look at family CEO transitions (see e.g. Bach, 2010). This would incorporate the idea that the firm is intended to be kept within the family. One advantage of using ultimate voting rights as identification is that it accounts for the case where a firm appoints an outside CEO while keeping indirect control of the firm through the majority of voting shares. If a CEO does not operate the way they want her to, they can simply replace her with another. There are however potential problems with using ultimate voting rights as a basis for the definition of family firms. Some of the theories presented in the previous section relied upon the fact that family firms were passed down through generations or that the owner and the manager is the same person. A drawback with this study is that the data does not allow for the distinction between family managers and family owner, or between descendant and professionally managed firms. However, for the majority of firms, these definitions will most likely overlap. Bjuggren et al. (2011) argue that it is likely that several family members have management responsibility and that multiple generations are involved in the firm when a family or individual controls more than 50 percent. $^{5}$

I used a stepwise procedure to identify family-owned firms. As a first step, all legal entities that according to definition cannot be family-owned, such as non-profit organizations and foundations, were excluded. The sample is also restricted to incorporated firms. Within the group of partnerships and sole-proprietorships there is again very little variation in ownership concentration. Incorporated firms constitute a vast number of firms in an economy and therefore it is not feasible to classify them one by one. The next step solves this problem by

\footnotetext{
${ }^{4}$ I will use the terms family firm and family-owned firm interchangeably.

${ }^{5}$ Bjuggren et al. (2011) investigated a sample of listed firms. In all of the firms, the main owner was actively involved, and they therefore deem it likely that this pattern is to be found also within smaller firms.
} 
making use of a tax reform in the early 1990s. The tax reform resulted in labor income tax for high-income earners being greater than capital income tax. In order to prevent high-income earners from exploiting this disparity, rules for closely-held firms where implemented. The rules apply only to non-listed incorporated firms, and as of 1993 the Swedish Tax Authority classifies all non-listed incorporated firms as closely held or not. ${ }^{6}$

A closely held firm is defined as a firm in which four or fewer owners together control more than 50 percent of the firm (Swedish Tax Authority 2008, part 3, chapter 9; and SFS 1999). To prevent owners from distributing shares to family members, the rules stipulate that family members are regarded as one owner (Swedish Tax Authority 2008, chapter 9, page 206). The Swedish Tax Authority registers keep track of all closely held firms and their exact number of owners. This register was matched with the firm data from Statistics Sweden and closely held firms with one or two owners where then identified as family firms to meet the 50 percent criterion. This is a conservative measure since there could be firms with three or more owners that still meet the 50 percent criterion. However, most of the closely held firms have a very concentrated ownership structure. For example, in 2006 more than 90 percent of the closely held firms had one or two owners. Finally, to identify listed family-owned firms I used the standard work on ownership in listed firms in Sweden, Owners and Power in Sweden's Listed Companies by Sundqvist (1993-2009).

Although the underlying data on closely held firms come from the Swedish Tax Authority, Statistics Sweden has made some changes in the way ownership concentration is measured. From 1997 to 2003, an individual was matched as an owner only to one single firm based on the main source of that individual's income. As of 2004, an individual is allowed to be registered as an owner of several closely held firms. This drastically increased the number of closely held firms, from 29 percent in 2003 to 49 percent in 2004. To be able to use the entire time dimension and make the data more comparable over time I have taken the ownership information from 2004 and imputed ownership status for the period 1997-2003. If a firm is registered as a closely held firm in 2004, but not in 1997-2003, I have coded it as closely held. This hinges on the assumption that these firms have not transferred from a dispersed ownership to being closely held in the six years before 2004. Most ownership changes are likely to take the opposite direction. A table with the number of family and non-family firms per year, using the imputed data, is presented in the Appendix, Table A1.

The data are restricted to firms with less than 500 employees. $^{7}$ There is very little variation in ownership concentration for larger firms. In total, only about 6 percent of the

\footnotetext{
${ }^{6}$ The Swedish Tax Authority also classifies all partnerships as closely held or not, although they do not abide by the same tax rules.

${ }^{7}$ The size restrictions do not apply to the sample of listed firms used in Table 4 .
} 
firms with more than 500 employees are identified as family firms. Moreover, the sample is restricted to not include industries such as fishing, forestry, and agriculture. A complete list of the included industries and the distribution based on ownership is found in the Appendix, Table A2.

Table 1 shows that about 44 percent of companies are family firms and they contribute to employment with about 29 percent. These figures are in line with previous research on the prevalence of family firms (see e.g. Bjuggren et al. 2011; Faccio and Lang 2002; La Porta et al. 1999; Anderson and Reeb 2003; and Bach 2010). The comparability with countries such as the US and France strengthens the argument of external validity. Looking at differences between family and non-family firms, Table 2 reveals that family firms are on average smaller, and sales and value added is lower. The main differences appear to be located in the top 75 percentiles. Moreover, family-owned firms are slightly older on average.

The size distribution of family and non-family firms is shown in Figure 1. There are relatively more family firms in the smaller size categories. As a point of reference, there are in total 59,752 family firms with five employees and the corresponding figure for non-family firms is 52,904. The geographical distribution of firms is shown in Figure 2. By using data

on establishments, I am able to locate firms according to municipality. The left map shows the distribution of the absolute number of firms over municipalities, 1997-2009. It becomes evident that most firms are located around the larger metropolitan areas: Malmö in the south, Gothenburg (Göteborg) on the west coast, and Stockholm on the east coast. The right map shows the distribution of the share of family firms in each municipality. The distribution reveals that family firms are relatively less frequent in the three large metropolitan areas.

\section{Industry Shocks}

The procedure in this section amounts to measuring fluctuations in firm performance at the industry level and see how it affects employment in the individual firm. Firm performance can be measured in a number of ways. I will use both sales and value added. Cardoso \& Portela (2009) argue that sales captures demand uncertainty since it directly reflects changes in product demand. Value added is according to Guiso et al. (2005) directly subject to stochastic fluctuations, and is not subject to discretionary reporting as for example profits.

In order to investigate family firm's employment behavior I model the sensitivity of employment to industry shocks based on the specification used by Sraer \& Thesmar (2007). They use fluctuations in total sales within an industry as their measure of shocks to firm performance. I will also add value added to the analysis. The following equation is estimated: 


$$
\ln Y_{i s t}=\alpha_{i s}+\beta\left(X_{i s t}\right) \ln x_{i s t}+\gamma\left(X_{i s t}\right) \delta_{t}+v_{i s t}
$$

where $Y_{i s t}$ is employment in firm $i$, industry $s$, at time $t, \alpha_{i s}$ is firm fixed effects, $\ln x_{i s t}$ is the logarithm of total sales or value added in industry $s$, minus the contribution of the specific firm $i$, and $\delta_{t}$ is a year dummy capturing possible business downturns. $\beta\left(X_{i s t}\right)$ is to be interpreted as elasticity to industry shocks and $\gamma\left(X_{i s t}\right)$ as elasticity to economic wide shocks. These elasticities are supposed to vary across firms according to the following:

$$
\begin{gathered}
\beta\left(X_{i s t}\right)=\beta+b F_{i s t}+c \ln \text { age }_{i s t}+d S O E_{i s t}+\Gamma_{i s t} e \\
\gamma\left(X_{i s t}\right)=\gamma+b^{\prime} F_{i s t}+c^{\prime} \ln a g e_{i s t}+d^{\prime} S O E_{i s t}+\Gamma_{i s t} e^{\prime}
\end{gathered}
$$

where $F_{i t}$ is a family firm dummy, $\ln a g e_{i t}$ is the natural logarithm of firm age, and $S O E_{i t}$ is a dummy variable taking the value one if firm $i$ has previously been state owned. ${ }^{8}$ Similar to France, Sweden has undergone a privatization of government-owned firms. $\Gamma_{i t}$ includes a dummy variable for being publicly listed, a dummy for belonging to a corporate group, and a dummy for operating in one of the greater metropolitan areas. ${ }^{9}$ The idea with this setting is to control for aggregate shocks and let firms vary in the response to industry-level fluctuations. Industry sales and value added might be correlated with the economy wide state $\delta_{t}$ and therefore, in the absence of equation $\gamma\left(X_{i} t\right)$, the estimates in $\beta\left(X_{i} t\right)$ might be biased. This will be the case if for example family firms have, overall, experienced a different growth rate than non-family firms during the time period 1997-2009. The equation $\gamma\left(X_{i} t\right)$ is thus controlling for aggregate shocks to the economy. In effect, putting the equations together, I am estimating the following:

$$
\begin{array}{r}
\ln Y_{i s t}=\alpha_{i s}+\beta \ln x_{i s t}+b F_{i s t} \ln x_{i s t}+c \ln a g e_{i s t} \ln x_{i s t}+d S O E_{i s t} \ln x_{i s t} \\
+\Gamma_{i s t} e \times \ln x_{i s t}+\gamma \delta_{t}+b^{\prime} F_{i s t} \delta_{t}+c^{\prime} \ln a g e_{i s t} \delta_{t}+d^{\prime} S O E_{i s t} \delta_{t}+\Gamma_{i s t} e^{\prime} \times \delta_{t}+v_{i s t}
\end{array}
$$

where $b$ measures the difference in elasticity of employment to industry fluctuations. A negative estimated coefficient $b$ would thus indicate that family firms respond less to sales or value added shocks within the industry. An implicit assumption in this setting is that aggregate industry sales and value added are exogenous to sales and value added in the individual firm. This implies that each firm has to be small enough not to affect the total within each industry.

\footnotetext{
${ }^{8} \mathrm{I}$ am not able to differentiate between different types of CEOs as done by Sraer \& Thesmar (2007).

${ }^{9}$ Note that these variables are not in the original specification by Sraer \& Thesmar (2007).
} 
The results from estimating the sensitivity of employment to industry shocks are presented in Table 3. All estimations include firm fixed effects, and columns (1) assume that $b^{\prime}=c^{\prime}=d^{\prime}=e^{\prime}=0$ in equation 3, i.e. that sales shocks within industries are uncorrelated with economy wide shocks. Columns (2)and (3) relaxes the assumption and columns (3) adds the variables in $\Gamma$ to the equations. The coefficient of particular interest is the interaction between shocks and family ownership, $\ln x_{s t} \times$ family firm. The estimations using sales as an outcome are shown in the three left most columns, and estimations using value added as an outcome are shown in the three right most columns. The results reveal a negative estimated coefficient for the interaction between industry fluctuation and family ownership for all models. This indicates that employment in family firms are less sensitive to industry sales and value added shocks.

In Table 4 the same setting is applied to the sample of listed firms. ${ }^{10}$ The most saturated model (3) using sales as an outcome indicates a positive coefficient, but contrary to the previous results by Sraer \& Thesmar (2007) there appears to be no persistent effect of family ownership. A possible explanation for the discrepancy is that Sraer \& Thesmar (2007) are able to differentiate between different types of CEOs: if the firm is run by a founder-CEO, an heir-CEO, or a professional CEO. It could be the case that the effect is offset when using an aggregate measure of ownership concentration. Moreover, some of the features that are believed to be specific to family firms, such as long term commitment, are features that can also be achieved by enlisting on the stock exchange.

\subsection{Disentangling Industry Shocks}

Sales and value added fluctuations at the industry level will capture both variation that is explained by a trend as well as unanticipated shocks to this trend. In order to separate the random component I introduce a first stage equation that aims to filter out the trend. ${ }^{11}$ More specifically, I let the second and final equation take the same form as before, with the exception of the definition of the shock, here denoted by $\epsilon_{i s t}$,

$$
Y_{i s t}=\alpha_{i s}+\beta\left(X_{i s t}\right) \epsilon_{i s t}+\gamma\left(X_{i s t}\right) \delta_{t}+v_{i s t}
$$

The unforeseen shock, $\epsilon_{i s t}$, is the residual from a first stage predictive equation on sales.

$$
S_{i s t}=\alpha_{i s}+\beta S_{i s, t-1}+\Gamma_{i s t} \kappa+\delta_{t}+\epsilon_{i s t},
$$

where $S_{i s, t-1}$ is the lagged logarithm of total sales or value added within an industry,

\footnotetext{
${ }^{10}$ There are no restrictions on size for this sample.

${ }^{11} \mathrm{I}$ am at this stage not assuming any specific structure of the error term.
} 
$\alpha_{i s}$ are fixed effects, and $\Gamma_{i t}$ is defined as before. Since the fixed effects are correlated with $S_{i s, t-1}$ the equation is estimated using the one-step first-differenced generalized method of moments (GMM) by Arellano \& Bond (1991). In the GMM stage, higher level of lags are used to instrument the one-period lagged logarithm of sales or value added. I will use lagged dependent variables in period t-4 as instruments. ${ }^{12}$ The GMM involves a step of first-differencing, which cancels out the fixed effects. The results from the GMM estimation is presented in Table 5 and 6 , and the observed serial correlations of the first-differenced residuals confirms the use of instruments lagged t-2 periods or earlier. The Hansen-J statistic indicates the validity of the instruments for the regressions on both sales and value added. The estimated coefficient on lagged sales, 0.63, represents the persistence of sales over time and the corresponding coefficient for lagged value added is slightly higher at 0.78.

The residuals are then used in equation (5), and the results are presented in Table 7. The interaction between the residual and the family firms indicator, $\epsilon_{s t} \times$ family firm, is still negative and statistically significant for both outcomes. The coefficients indicate that family firms are less sensitive to unanticipated fluctuations at the industry level. This reinforce the idea that family firms are less sensitive to shocks, and indicates that the previous effect on total industry fluctuation were not merely a result of family firms following a different trend on average.

\section{$4 \quad$ Firm level shocks}

Estimating responses to shocks within an industry could be misleading if for example family firms are systematically less exposed to shocks. Estimating a shock at the firm level would mitigate this potential problem. Moreover, aggregate industry shocks are common to all firms within the industry and the risk is therefore less diversifiable. In the following section I will estimate firm level shocks using the specification proposed by Guiso et al. (2005). ${ }^{13}$ The idea briefly amounts to estimating firm performance and employment separately, and using the residuals from these regressions to capture idiosyncratic shocks. The residual from the employment estimation is regressed on the firm performance residual using different leads and lags as instruments to investigate both permanent and temporary shocks. Similar to the previous setting, sales and value added are determined by

$$
S_{i t}=\alpha_{i}+\rho S_{i, t-1}+X_{i t} \theta+\epsilon_{i t},
$$

\footnotetext{
${ }^{12}$ The instruments are limited to t- 4 as to avoid problems with over-identification.

${ }^{13}$ See also Cardoso \& Portela (2009) for an application on Portuguese data, and Kátay (2008) for an application on Hungarian data.
} 
where $S_{i, t}$ is the logarithm of sales in firm $i$ at time $t, X_{i t}$ is a vector of controls including covariates from previous estimations ${ }^{14}$, and $\alpha_{i}$ is the firm specific effect. Since the fixed effects $\alpha_{i}$ are correlated with $S_{i, t-1}$, OLS is inconsistent, and I will again use the generalized method of moments (GMM) by Arellano \& Bond (1991). I will use lagged dependent variables from period t-5 as instruments for the sales regression, and for the value added regressions I will use the lagged dependent variable in $\mathrm{t}-7 .{ }^{15}$

I report the results for the GMM in Table 8 and 9. Persistence of sales and value added is estimated to 0.87 and 0.89 , respectively. The validity of the instruments used in the regression on value added, Table 6 , are confirmed by the Hansen J-test. The first differenced residuals show that the first and second lag are significant and becomes insignificant at lag 3. This is similar to the results by Guiso et al. (2005), Cardoso \& Portela (2009), and Kátay (2008), and is consistent with an MA(2) process.

The regression on sales in Table 8 does not pass the test of over-identification. Using lagged sales in period t-7 and earlier instead will result in a satisfactory Hansen-J statistic with a p-value of $0.38 .{ }^{16}$ However, the persistence of sales is then estimated to be 2.4 , which might be of concern. As a robustness check, all estimations are replicated in Appendix, Table A4 and A5, using this alternate specification.

Following Guiso et al. (2005), the error term can be decomposed into a random walk and an $\mathrm{MA}(1)$ process respectively, such that

$$
\begin{array}{r}
\epsilon_{i t}=\zeta_{i t}+\tilde{\nu}_{i t}-\theta \tilde{\nu}_{i, t-1}, \\
\zeta_{i t}=\zeta_{i, t-1}+\tilde{u}_{i t} .
\end{array}
$$

The autocovariance of $\Delta \epsilon_{i t}$ is thus consistent with the structure in Table 9 and goes to zero after 3 periods under the assumption that $E\left(\tilde{u}_{i t}^{2}\right)=\sigma_{\tilde{u}}^{2}$, and $E\left(\tilde{\nu}_{i t}^{2}\right)=\sigma_{\tilde{\nu}}^{2}$ for all $t$, $E\left(\tilde{\nu}_{i s}^{2} \tilde{\nu}_{i t}^{2}\right)=E\left(\tilde{u}_{i s}^{2} \tilde{u}_{i t}^{2}\right)=0$ for $s \neq t$, and $E\left(\tilde{\nu}_{i s}^{2} \tilde{u}_{i t}^{2}\right)=0$ for all $s$ and $t$.

On the basis of this representation, I rewrite the equation (7) as the sum of a deterministic $D_{i t}$, a permanent $P_{i t}$, and a transitory component $T_{i t}$ :

$$
S_{i t}=D_{i t}+P_{i t}+T_{i t}
$$

\footnotetext{
${ }^{14}$ The covariates include the logarithm of firm age, a dummy variable for being publicly listed, a dummy for belonging to a corporate group, and a dummy for operating in one of the greater metropolitan areas.

${ }^{15}$ I choose to use deeper lags in order to reduce the number of instruments. To make sure that the specific selection of instruments does not alter the main results, I will run the same estimations where instruments are chose strictly according to assumptions on the error term and independent of potential over-identification (see Table A6 and A7).

${ }^{16}$ The lags 7-12 are collapsed so that there are one instrument for each variable and lag distance, rather than for each time period, variable and lag distance.
} 
where, using $L$ as a lag operator, $(1-\rho L)^{-1} \epsilon_{i t}=P_{i t}+T_{i t}$ so that $D_{i t}=(1-\rho L)^{-1}\left(\alpha_{i}+\right.$ $\left.\theta^{\prime} X_{i t}\right)$. Moreover, Guiso et al. (2005) show that $P_{i t}=(1-\rho L)^{-1} \zeta_{i t}$, and $T_{i t}=(1-\rho L)^{-1}((1-$ $\left.\theta L) \tilde{\nu}_{i t}-(1-\rho)^{-1} \rho \tilde{u}_{i t}\right)$.

Taking first differences, I can rewrite the error term, $(1-\rho L)^{-1} \epsilon_{i t}=P_{i t}+T_{i t}$, as

$$
\Delta \epsilon_{i t}=(1-\rho L) u_{i t}+\Delta \nu_{i t}
$$

where

$$
u_{i t}=\frac{1}{1-\rho} \tilde{u}_{i t}
$$

and

$$
\nu_{i t}=(1-\theta L) \tilde{\nu}_{i t}-\frac{\rho}{1-\rho} \tilde{u}_{i t}
$$

I will assume that employment in a firm can be represented by the following equation

$$
E m p_{i t}=X_{i t} \Phi+\varphi_{i}+\alpha P_{i t}+\beta T_{i t}+\psi_{i t}
$$

where $E m p_{i t}$ is employment in firm $i$ at time $t$, and $X_{i t}$ is defined as before. Using the same argument that Guiso et al. (2005) use on wages, I let the last four terms constitute the error term and divide it into a fixed effect $\varphi_{i}$, a permanent shock $P_{i}$, a temporary shock $T_{i t}$, and an error term $\psi_{i t}$ that is assumed to be uncorrelated with $P_{i t}$ and $T_{i t}$. Employment is assumed to respond to permanent and temporary shocks with the sensitivities $\alpha$ and $\beta$ respectively. I then multiply equation (13) by $(1-\rho L)$, where $L$ is a lag operator, and the process of employment takes the form

$$
E m p_{i t}=\rho E m p_{i, t-1}+(1-\rho L) X_{i t} \Phi+(1-\rho L)\left(\varphi_{i}+\alpha P_{i t}+\beta T_{i t}+\psi_{i t}\right)
$$

and the error term can be defined as

$$
\omega_{i t}=(1-\rho L)\left(\varphi_{i}+\alpha P_{i t}+\beta T_{i t}+\psi_{i t}\right) .
$$

The transformation thus introduces state dependence on employment. Like before, I use the one-step first-differenced GMM to estimate the equation. I use employment lagged 6-9 periods to instrument employment in time $t-1 .{ }^{17}$ The control variables in $X_{i t}$ are assumed to be exogenous. The results are presented in Table 10 and the estimated coefficient

\footnotetext{
${ }^{17}$ Also here I have collapsed the instruments so that there are one instrument for each variable and lag distance in order to reduce the number of instruments used.
} 
for employment is 0.97 , which indicates a high degree of persistence. The test for overidentifying restrictions indicates that the instruments are valid. However, the first-differenced errors show serial correlation in the first and second lag but not the third. The assumed structure of the error term implies an $\mathrm{MA}(3)$ process that is not obvious from the observed serial correlation in Table 10. Although the exact structure of the error term $\omega_{i t}$ is not confirmed, the instruments are validated by the Hansen test of over-identification and since I use employment lagged 6-9 periods as instruments, I allow for potential serial correlation also in the third lag.

Finally, the strategy proposed by Guiso et al. (2005) boils down to estimating $\alpha$ and $\beta$ through regressing the residuals from the employment process $\Delta \omega_{i t}$ on the residuals from the sales equation $\Delta \epsilon_{i t}$. Taking first differences and using the definition of $P$ and $T$ from above, together with equation 11 and 12, the residual from the process of employment can be rewritten as $\Delta \omega_{i t}=\alpha(1-\rho L) u_{i t}+\beta \Delta \nu_{i t}+(1-\rho L) \Delta \psi_{i t}$, where the fixed effects cancel out. Recall from above that the first difference of the residual from the sales equation can be written as $\Delta \epsilon_{i t}=(1-\rho L) u_{i t}+\Delta \nu_{i t}$. The coefficients of interest, $\alpha$ and $\beta$, are recovered by estimating two separate IV regressions of $\Delta \omega_{i t}$ on $\Delta \epsilon_{i t}$. Guiso et al. (2005) show that $\alpha$ can be estimated based on the instruments $\left(\sum_{\tau=-2}^{2} \Delta \epsilon_{i, t+\tau}\right)^{k}$, and $\beta$ can be estimated based on the instruments $\left(\Delta \epsilon_{i, t+1}\right)^{k}$, for any $k \geq 1$. These instruments are then interacted with the family firm dummy to capture the heterogeneity in ownership concentration.

To estimate both $\alpha$ and $\beta$ I have used the feasible efficient GMM procedure. Instruments are defined for $k=1,2,3$ in each regression and the results are shown in Table 11 and 12 . Estimations on temporary shocks, Table 11, indicate that family firms are less anxious to translate shocks in value added and sales into employment changes. This is in line with the previous estimations on the industry level, suggesting that family firms are less sensitive to temporary shocks at the firm level. When I have instrumented $\Delta \epsilon_{i t}$ with the one period lead for $k=1$, the regressors are exactly identified. Using the residuals from the value added regression in Table 6 and instrumenting for $k=3$, results in a satisfactory p-value for the Hansen-J statistic, indicating that the instruments are valid. For $k=2$ the p-value is slightly lower at 0.02 , and does not satisfy the 5 percent significance level. Using the residuals from the sales regression does not satisfy the over-identification test for either $k=3$ or $k=2$. The results are thus to be considered as tentative. The estimations trying to capture permanent shocks in Table 12 show no persistent significant effect of family ownership. The models are not however confirmed by the over-identifying test, which indicates that the equations are potentially miss-specified.

The above results give some indications that family firms are behaving like any other firm when hit by permanent shocks, such as large technology changes, but are less inclined to 
make employment changes when hit by temporary shocks, such as machinery breakdown and temporary sales shocks. A rationale for this could be that when the future of the firm is at stake, which is more likely when hit by a permanent shock, family firms have at least as strong incentives, if not stronger, to make sure that the firm stays alive. When hit by a temporary shock, the family firms features of long term commitment, being more easily identified with the company and its actions, and willingness to accept below-target performance in order to avoid the loss of socioemotional wealth, could make them less anxious to adjust their workforce.

The results should be viewed as tentative since; i) the assumed structure of the error term from the employment equation is not verified by the observed serial correlation in the first-differenced errors, ii) the iv estimations on permanent shocks are not validated by the Hansen J-test for over-identification. In the regressions on sales, value added and employment (Table 8, 6, 10), I have adjusted the depth and number of lags used to reduce the number of instruments in order to avoid over-identification. To make sure that this does not change the main results I have included regressions in Appendix (Table A6, A7, A8, A9 A10), where I have replicated all the steps, instrumenting with lags solely on the basis of the implied structure of the error terms. Hence, I have used lags in period $t-3$ and earlier for sales and value added, and lags in period $t-4$ and earlier for employment. ${ }^{18}$ The results are shown in Table A9 and A10, and confirms the previous findings. None of these estimations however pass the Hansen-J test of over-identification.

\section{Conclusions}

This paper provides empirical evidence that employment in family firms is less sensitive to product market and performance fluctuations. Family firms are believed to have longer time horizons and are as managers and owners more easily identified with their company. These are features that could make family firms more cautious in terms of hiring and firing and thus enable them to offer their employees implicit employment protection. Sraer \& Thesmar (2007) investigated how publicly listed family firms react to shocks in performance, and their findings seem to confirm this hypothesis. The previous empirical evidence is however based only on listed firms where shocks are defined as sales fluctuations at the industry level. In this paper I investigated how employment in family firms responds to shocks in sales and value added, both aggregate shocks at the industry level and idiosyncratic firm level shocks. I used full population data, which allowed me to identify all family-owned firms in the economy, both listed and non-listed firms. This has previously not been feasible.

\footnotetext{
${ }^{18}$ These are also the instruments chosen by Guiso et al. (2005)
} 
As a first step I confirmed the findings by Sraer \& Thesmar (2007) and showed that family firms are less sensitive to industry sales shocks. I then extended the analysis and found that it also holds for fluctuations in value added. However, contrary to the results found by Sraer \& Thesmar (2007), listed firms in Sweden do not show a similar sensitivity to shocks. A possible explanation for the discrepancy is that Sraer \& Thesmar (2007) are able to differentiate between different types of CEOs: if the firm is run by a founder-CEO, an heir-CEO, or a professional CEO. It could be the case that the effect is offset when using the aggregate measure. Moreover, some of the family firm features, such as long term commitment, could also be achieved by enlisting on the stock exchange.

Investigating sales and value added fluctuations at the industry level will capture both variation that is explained by a trend as well as unanticipated shocks to this trend. I proceeded by filtering out the trend in industry sales and value added fluctuations in order to isolate the unanticipated component. Employment in family firms is found to be less sensitive also to this measure of an unanticipated shock at the industry level.

Using variation at the industry level could be misleading if family firms are systematically less exposed to shocks. This justifies the focus on idiosyncratic shocks at the firm level. To investigate how family firms respond to idiosyncratic shocks to product market and performance fluctuations I relied on the framework by Guiso et al. (2005) and estimated the response to permanent and transitory shocks, respectively. The results should be considered as tentative but indicate that family firms are less sensitive to temporary demand shocks.

Hence, family firms appear to be less anxious to translate temporary shocks in performance and product demand into changes in employment.

To sum up, the empirical evidence presented in this paper shows that family firms are less sensitive to performance and product market fluctuations, which supports the idea that family firms offer their employees implicit employment protection. This paper also stresses the importance of modeling heterogeneity in firm ownership when it comes to risk-sharing and labor demand adjustments.

\section{References}

Anderson, R. C. \& Reeb, D. M. (2003), 'Founding-family ownership and firm performance: Evidence from the S\&P 500', Journal of Finance 58(3), 1301-1327.

Arellano, M. \& Bond, S. (1991), 'Some tests of specification for panel data: Monte carlo evidence and an application to employment equations', Review of Economic Studies 58(2), 277-97.

Astrachan, J. H. \& Shanker, M. C. (2003), 'Family businesses' contribution to the U.S. economy: A closer look', Family Business Review 16(3), 211-219. 
Bach, L. (2010), Why are family firms so small?, Working Paper Series 3464, Paris December 2010 Finance Meeting EUROFIDAI - AFFI.

Bach, L. \& Serrano-Velarde, N. (2011), CEO identity and labor contracts: Theory and evidence from CEO transitions, Working paper, IGIER, Universit Bocconi.

Bandiera, O., Prat, A., Guiso, L. \& Sadun, R. (2011), Matching firms, managers and incentives, NBER Working Papers 16691, National Bureau of Economic Research, Inc.

Bassanini, A., Caroli, E., Rebérioux, A. \& Breda, T. (2013), 'Working in family firms: Less paid but more secure? evidence from French matched employer-employee data', Industrial and Labor Relations Review 66(2), 433-466.

Berrone, P., Cruz, C. \& Gomez-Mejia, L. R. (2012), 'Socioemotional wealth in family firms: Theoretical dimensions, assessment approaches, and agenda for future research', Family Business Review 25(3), 258-279.

Bertrand, M. \& Schoar, A. (2006), 'The role of family in family firms', Journal of Economic Perspectives 20(2), 73-96.

Bjuggren, C. M., Johansson, D. \& Sjögren, H. (2011), 'A note on employment and gross domestic product in Swedish family-owned businesses: A descriptive analysis', Family Business Review 24(4), 362-371.

Block, J. (2010), 'Family management, family ownership, and downsizing: Evidence from S\&P 500 firms', Family Business Review 23(2), 109-130.

Cardoso, A. R. \& Portela, M. (2009), 'Micro foundations for wage flexibility: Wage insurance at the firm level', Scandinavian Journal of Economics 111(1), 29-50.

Chandler, A. D. \& Hikino, T. (1990), Scale and Scope: The Dynamics of Industrial Capitalism, Belknap Press, Cambridge, Mass.

Choudhary, M. A. \& Levine, P. (2010), 'Risk-averse firms and employment dynamics', Oxford Economic Papers 62(3), 578-602.

D'Aurizio, L. \& Romano, L. (2013), Family firms and the great recession: out of sight, out of mind?, Temi di discussione (Economic working papers) 905, Bank of Italy, Economic Research and International Relations Area.

Davis, S. J., Haltiwanger, J., Jarmin, R. \& Miranda, J. (2007), Volatility and dispersion in business growth rates: Publicly traded versus privately held firms, in 'NBER Macroeconomics Annual 2006, Volume 21', NBER Chapters, National Bureau of Economic Research, Inc, pp. 107-180.

Dyer, W. G. \& Whetten, D. A. (2006), 'Family firms and social responsibility: Preliminary evidence from the S\&P 500', Entrepreneurship Theory and Practice 30(6), 785-802. 
Ellul, A., Pagano, M. \& Shivardi, F. (2013), Risk sharing within firms: Worldwide evidence, Conference paper, 1ST CSEF Conference on Finance and Labor.

URL: http://www.csef.it/FINLAB_Conference/Schivardi.pdf

Faccio, M. \& Lang, L. H. P. (2002), 'The ultimate ownership of Western European corporations', Journal of Financial Economics 65(3), 365-395.

Gómez-Meja, L. R., Haynes, K. T., Núñez Nickel, M., Jacobson, K. J. L. \& Moyano-Fuentes, J. (2007), 'Socioemotional wealth and business risks in family-controlled firms: Evidence from spanish olive oil mills', Administrative Science Quarterly 52(1), 106-137.

Guiso, L., Pistaferri, L. \& Schivardi, F. (2005), 'Insurance within the firm', Journal of Political Economy 113(5), 1054-1087.

Kátay, G. (2008), Do firms provide wage insurance against shocks? Evidence from Hungary, Working Paper Series 0964, European Central Bank.

La Porta, R., Lopez-De-Silanes, F. \& Shleifer, A. (1999), 'Corporate ownership around the world', Journal of Finance 54(2), 471-517.

Landes, D. S. (1949), 'French entrepreneurship and industrial growth in the nineteenth century', The Journal of Economic History 9(01), 45-61.

Lee, J. (2006), 'Family firm performance: Further evidence', Family Business Review 19(2), 103-114.

Miller, D. \& Le Breton-Miller, I. (2006), 'Family governance and firm performance: Agency, stewardship, and capabilities', Family Business Review 19(1), 73-87.

Morck, R. (2000), Concentrated Corporate Ownership, University of Chicago Press, Chicago.

Morck, R., Wolfenzon, D. \& Yeung, B. (2005), 'Corporate governance, economic entrenchment, and growth', Journal of Economic Literature 43(3), 655-720.

Shanker, M. C. \& Astrachan, J. H. (1996), 'Myths and realities: Family businesses' contribution to the US economy? A framework for assessing family business statistics', Family Business Review 9(2), 107-123.

Shleifer, A. \& Summers, L. H. (1988), Breach of trust in hostile takeovers, in 'Corporate Takeovers: Causes and Consequences', National Bureau of Economic Research, Inc, pp. 33-68.

Sraer, D. \& Thesmar, D. (2007), 'Performance and behavior of family firms: Evidence from the french stock market', Journal of the European Economic Association 5(4), 709-751.

Statistics Sweden (2008), 'Background facts, labour and education statistics 2008:1, integrated database for labour market research'. 
Stavrou, E., Kassinis, G. \& Filotheou, A. (2007), 'Downsizing and stakeholder orientation among the Fortune 500: Does family ownership matter?', Journal of Business Ethics 72(2), 149-162.

Stiglitz, J. E. (1987), Design of labor contracts: Economics of incentives and risk-sharing, in H. R. Nalbantian, ed., 'Incentives, Cooperation, and Risk Sharing : Economic and Psychological Perspectives on Employment Contracts', Rowman \& Littlefield, Totowa, N.J., pp. 47-68.

Wiklund, J. (2006), 'Commentary: Family firms and social responsibility: Preliminary evidence from the S\&P 500', Entrepreneurship Theory and Practice 30(6), 803-808. 


\section{A Tables}

Table 1: Share of family firms

\begin{tabular}{lcc}
\hline & family firms & non-family firms \\
\hline Share of firms & 0.4386 & 0.5614 \\
Share of Employment & 0.2867 & 0.7123 \\
Observations & 332,339 & 425,380 \\
\hline
\end{tabular}

Table 2: Characteristics of family firms

\begin{tabular}{lccccc}
\hline & Family firms & & & & \\
& $\mathrm{N}$ & mean & $\mathrm{p} 25$ & $\mathrm{p} 50$ & $\mathrm{p} 75$ \\
\hline \multirow{2}{*}{ Employment } & 332,339 & 14.04 & 6 & 8 & 14 \\
Sales & 317,997 & 18,149 & 4,522 & 7,975 & 16,424 \\
Value added & 317,997 & 6,030 & 2,039 & 3,254 & 5,808 \\
Age & 332,339 & 7.592 & 2 & 6 & 13 \\
Listed & 332,339 & 0.00179 & 0 & 0 & 0 \\
SOE & 332,339 & 0.000560 & 0 & 0 & 0 \\
Metro & 316,466 & 0.346 & 0 & 0 & 1 \\
Corporate group & 332,339 & 0.171 & 0 & 0 & 0 \\
& & & & & \\
\hline & Non-family firms & & & & \\
& $\mathrm{N}$ & mean & $\mathrm{p} 25$ & $\mathrm{p} 50$ & $\mathrm{p} 75$ \\
\hline & & & & & \\
Employment & 425,380 & 27.28 & 7 & 12 & 24 \\
Sales & 392,653 & 55,513 & 5,778 & 12,898 & 35,282 \\
Value added & 392,653 & 14,739 & 2,347 & 4,812 & 11,649 \\
Age & 425,380 & 7.046 & 1 & 5 & 12 \\
Listed & 425,380 & 0.00447 & 0 & 0 & 0 \\
SOE & 425,380 & 0.00514 & 0 & 0 & 0 \\
Metro & 376,719 & 0.473 & 0 & 0 & 1 \\
Corporate group & 425,380 & 0.515 & 0 & 1 & 1 \\
\hline
\end{tabular}

Note: Sales and value added are measured in thousands of krona (SEK). Metro corresponds to a dummy variable for the three greater metropolitan areas around Stockholm, Göteborg, and Malmö. 
Table 3: Sensitivity of employment to industry shocks

\begin{tabular}{|c|c|c|c|c|c|c|}
\hline & \multicolumn{3}{|c|}{$x=$ sales } & \multicolumn{3}{|c|}{$x=$ value added } \\
\hline & (1) & $(2)$ & $(3)$ & (1) & (2) & $(3)$ \\
\hline $\ln x_{s t}$ & $\begin{array}{l}-0.00474 \\
(0.00309)\end{array}$ & $\begin{array}{l}-0.00437 \\
(0.00318)\end{array}$ & $\begin{array}{l}-0.00688^{*} \\
(0.00393)\end{array}$ & $\begin{array}{l}-0.00393 \\
(0.00378)\end{array}$ & $\begin{array}{l}-0.00433 \\
(0.00386)\end{array}$ & $\begin{array}{l}-0.00851^{*} \\
(0.00490)\end{array}$ \\
\hline $\ln x_{s t} \times$ family firm & $\begin{array}{l}-0.000606^{* * *} \\
(0.000108)\end{array}$ & $\begin{array}{l}-0.00709^{* * * *} \\
(0.00179)\end{array}$ & $\begin{array}{l}-0.00774 * * * \\
(0.00182)\end{array}$ & $\begin{array}{l}-0.000475^{* * *} \\
(0.000121)\end{array}$ & $\begin{array}{l}-0.00704^{* * *} \\
(0.00229)\end{array}$ & $\begin{array}{l}-0.00717^{* * *} \\
(0.00238)\end{array}$ \\
\hline $\ln x_{s t} \times \ln a g e_{i t}$ & $\begin{array}{l}0.00711^{* * *} \\
(0.00117)\end{array}$ & $\begin{array}{l}0.00776^{* * *} \\
(0.00117)\end{array}$ & $\begin{array}{l}0.00895^{* * *} \\
(0.00119)\end{array}$ & $\begin{array}{l}0.00832^{* * *} \\
(0.00151)\end{array}$ & $\begin{array}{l}0.00927^{* * *} \\
(0.00151)\end{array}$ & $\begin{array}{l}0.0103^{* * *} \\
(0.00158)\end{array}$ \\
\hline $\ln x_{s t} \times \mathrm{SOE}$ & $\begin{array}{l}0.0361 \\
(0.0335)\end{array}$ & $\begin{array}{l}0.0414 \\
(0.0397)\end{array}$ & $\begin{array}{l}0.0474 \\
(0.0532)\end{array}$ & $\begin{array}{l}0.0206 \\
(0.0213)\end{array}$ & $\begin{array}{l}0.0211 \\
(0.0253)\end{array}$ & $\begin{array}{l}0.0158 \\
(0.0280)\end{array}$ \\
\hline $\ln x_{s t} \times$ listed & $\begin{array}{l}0.00896^{* * *} \\
(0.00170)\end{array}$ & $\begin{array}{l}0.0179 \\
(0.0221)\end{array}$ & $\begin{array}{l}-0.00307 \\
(0.0220)\end{array}$ & $\begin{array}{l}0.00796^{* * *} \\
(0.00170)\end{array}$ & $\begin{array}{l}0.00528 \\
(0.0230)\end{array}$ & $\begin{array}{l}-0.00772 \\
(0.0251)\end{array}$ \\
\hline $\ln a g e_{i t}$ & $\begin{array}{l}-0.0553^{* * *} \\
(0.0213)\end{array}$ & $\begin{array}{l}-0.0906^{* * *} \\
(0.0211)\end{array}$ & $\begin{array}{l}-0.110^{* * *} \\
(0.0215)\end{array}$ & $\begin{array}{l}-0.0759^{* * *} \\
(0.0255)\end{array}$ & $\begin{array}{l}-0.123^{* * *} \\
(0.0253)\end{array}$ & $\begin{array}{l}-0.137^{* * *} \\
(0.0266)\end{array}$ \\
\hline $\ln x_{s t} \times$ corp. group & & & $\begin{array}{l}-0.00217 \\
(0.00209)\end{array}$ & & & $\begin{array}{l}0.00444^{*} \\
(0.00251)\end{array}$ \\
\hline $\ln x_{s t} \times$ metro & & & $\begin{array}{l}0.00686 \\
(0.00451)\end{array}$ & & & $\begin{array}{l}0.00171 \\
(0.00556)\end{array}$ \\
\hline Year FE & yes & yes & yes & yes & yes & yes \\
\hline Firm FE & yes & yes & yes & yes & yes & yes \\
\hline Year FE x family firm & no & yes & yes & no & yes & yes \\
\hline Year FE x ln age & no & yes & yes & no & yes & yes \\
\hline Year FE x SOE & no & yes & yes & no & yes & yes \\
\hline Year FE x listed & no & yes & yes & no & yes & yes \\
\hline Year FE x corp. group & no & no & yes & no & no & yes \\
\hline Year FE x metro & no & no & yes & no & no & yes \\
\hline Observations & 595,104 & 595,104 & 542,131 & 441,001 & 441,001 & 401,091 \\
\hline R-squared & 0.077 & 0.083 & 0.088 & 0.064 & 0.070 & 0.075 \\
\hline Number of firms & 132,846 & 132,846 & 125,662 & 108,208 & 108,208 & 101,938 \\
\hline
\end{tabular}

Dependent variable is ln employment $i t$. Robust standard errors in parentheses. *** $\mathrm{p}<0.01,{ }^{* *} \mathrm{p}<0.05,{ }^{*} \mathrm{p}<0.1$ 
Table 4: Sensitivity of employment to industry shocks in publicly listed firms

\begin{tabular}{lllllll}
\hline & & $x=$ sales & \multicolumn{3}{c}{$x=$ value added } \\
& $(1)$ & $(2)$ & $(3)$ & $(1)$ & $(2)$ & $(3)$ \\
\hline $\ln x_{s t}$ & 0.0100 & 0.00102 & -0.0305 & 0.0157 & 0.0116 & -0.0505 \\
& $(0.0209)$ & $(0.0230)$ & $(0.0458)$ & $(0.0206)$ & $(0.0248)$ & $(0.0515)$ \\
$\ln x_{s t} \times$ family firm & -0.000706 & 0.0226 & $0.0417^{* *}$ & 0.00230 & 0.0200 & 0.0410 \\
& $(0.00297)$ & $(0.0171)$ & $(0.0209)$ & $(0.00360)$ & $(0.0229)$ & $(0.0310)$ \\
$\ln x_{s t} \times \ln$ age $e_{i t}$ & 0.00585 & 0.00545 & 0.0204 & 0.00676 & 0.00604 & 0.0179 \\
& $(0.0115)$ & $(0.0109)$ & $(0.0131)$ & $(0.0115)$ & $(0.0120)$ & $(0.0149)$ \\
$\ln x_{s t} \times$ SOE & 0.0132 & 0.00601 & $0.0476^{* *}$ & 0.00736 & 0.0212 & -2.679 \\
& $(0.0318)$ & $(0.0179)$ & $(0.0227)$ & $(0.0788)$ & $(0.0515)$ & $(5.073)$ \\
$\ln a g e_{i t}$ & -0.131 & -0.222 & $-0.497^{* *}$ & -0.155 & -0.195 & $-0.407^{*}$ \\
& $(0.187)$ & $(0.191)$ & $(0.220)$ & $(0.179)$ & $(0.194)$ & $(0.228)$ \\
$\ln x_{s t} \times$ corp. group & & & -0.0337 & & & $0.0557^{*}$ \\
& & & $(0.0208)$ & & & $(0.0302)$ \\
$\ln x_{s t} \times$ metro & & & $0.0582^{* *}$ & & & 0.00846 \\
& & & $(0.0272)$ & & & $(0.0313)$ \\
Year FE & & & & & & \\
Firm FE & yes & yes & yes & yes & yes & yes \\
Year FE x family firm & yes & yes & yes & yes & yes & yes \\
Year FE x ln age & no & yes & yes & yos & yes & yes \\
Year FE x SOE & no & yes & yes & no & yes & yes \\
Year FE x corp. group & no & no & yes & no & yes & yes \\
Year FE x metro & no & no & yes & no & no & yes \\
Observations & & & & & & \\
R-squared & 2,237 & 2,237 & 1,676 & 1,563 & 1,563 & 1,166 \\
Number of firms & 0.068 & 0.098 & 0.166 & 0.036 & 0.060 & 0.119 \\
\hline Depend & 610 & 610 & 493 & 478 & 478 & 381 \\
\hline
\end{tabular}

Dependent variable is ln employment $t_{i t}$. Robust standard errors in parentheses.

*** $\mathrm{p}<0.01, * * \mathrm{p}<0.05, * \mathrm{p}<0.1$ 
Table 5: Industry sales GMM regression

\begin{tabular}{lll}
\hline Variable & \multicolumn{2}{c}{ Estimate } \\
\hline ln Sales at $t-1$ & 0.6330 & $(0.1154)$ \\
& & \\
Metro & -0.0169 & $(0.0250)$ \\
Corp. group & -.0049 & $(0.0040)$ \\
Listed & 0.0821 & $(0.0533)$ \\
Year FE & 11651.43 & {$[0.000]$} \\
& & \\
Hansen J-test & 11.00 & {$[0.202]$} \\
AR(1) test & -5.83 & {$[0.000]$} \\
AR(2) test & 0.01 & {$[0.991]$} \\
& & \\
Observations & 334,359 & \\
Number of firms & 71,155 & \\
\hline
\end{tabular}

Dependent variable is the logarithm of total value added within an industry at time $t$. Estimated by the first-differenced GMM, using robust standard errors. Instruments are discussed in the text. For year dummies the joint F- statistic is reported. Standard errors in parentheses. $\mathrm{P}$-values in brackets.
Table 6: Industry value added GMM regression

\begin{tabular}{lll}
\hline Variable & \multicolumn{2}{c}{ Estimate } \\
\hline ln Value added at $t-1$ & 0.7829 & $(0.2173)$ \\
& & \\
Metro & -0.0094 & $(0.0306)$ \\
Corp. group & -0.0001 & $(0.0039)$ \\
Listed & 0.0815 & $(0.0725)$ \\
Year FE & 3573.90 & {$[0.000]$} \\
& & \\
Hansen J-test & 5.86 & {$[0.321]$} \\
AR $(1)$ test & -3.91 & {$[0.000]$} \\
AR(2) test & 1.69 & {$[0.091]$} \\
& & \\
Observations & 231,695 & \\
Number of firms & 57,623 & \\
\hline
\end{tabular}

Dependent variable is the logarithm of total sales within an industry at time $t$. Estimated by the first-differenced GMM, using robust standard errors. Instruments are discussed in the text. For year dummies the joint F-statistic is reported. Standard errors in parentheses. $\mathrm{P}$-values in brackets. 
Table 7: Sensitivity of employment to unanticipated industry shocks

\begin{tabular}{|c|c|c|c|c|c|c|}
\hline & \multicolumn{3}{|c|}{$\epsilon=$ sales residual } & \multicolumn{3}{|c|}{$\epsilon=$ value added residual } \\
\hline & (1) & $(2)$ & (3) & (1) & $(2)$ & $(3)$ \\
\hline$\epsilon_{s t}$ & $\begin{array}{l}-0.0152^{* * *} \\
(0.00457)\end{array}$ & $\begin{array}{l}-0.0151^{* * *} \\
(0.00454)\end{array}$ & $\begin{array}{l}-0.0177^{* * *} \\
(0.00539)\end{array}$ & $\begin{array}{l}-0.0135^{* * *} \\
(0.00489)\end{array}$ & $\begin{array}{l}-0.0132^{* * *} \\
(0.00486)\end{array}$ & $\begin{array}{c}-0.0164^{* * *} \\
(0.00598)\end{array}$ \\
\hline$\epsilon_{s t} \times$ family firm & $\begin{array}{l}-0.0121^{* * *} \\
(0.00356)\end{array}$ & $\begin{array}{l}-0.0125^{* * *} \\
(0.00354)\end{array}$ & $\begin{array}{l}-0.0131^{* * *} \\
(0.00364)\end{array}$ & $\begin{array}{l}-0.00819^{* *} \\
(0.00409)\end{array}$ & $\begin{array}{l}-0.00851^{* *} \\
(0.00406)\end{array}$ & $\begin{array}{c}-0.00813^{*} \\
(0.00450)\end{array}$ \\
\hline$\epsilon_{s t} \times \ln a g e_{i t}$ & $\begin{array}{l}0.0148^{* * *} \\
(0.00224)\end{array}$ & $\begin{array}{l}0.0144^{* * *} \\
(0.00222)\end{array}$ & $\begin{array}{l}0.0151^{* * *} \\
(0.00222)\end{array}$ & $\begin{array}{l}0.00972^{* * *} \\
(0.00247)\end{array}$ & $\begin{array}{l}0.00965^{* * *} \\
(0.00245)\end{array}$ & $\begin{array}{c}0.0104^{* * *} \\
(0.00246)\end{array}$ \\
\hline$\epsilon_{s t} \times \mathrm{SOE}$ & $\begin{array}{l}0.0201 \\
(0.0362)\end{array}$ & $\begin{array}{l}0.0220 \\
(0.0357)\end{array}$ & $\begin{array}{l}0.0213 \\
(0.0356)\end{array}$ & $\begin{array}{l}0.0110 \\
(0.0150)\end{array}$ & $\begin{array}{l}0.00938 \\
(0.0147)\end{array}$ & $\begin{array}{l}0.00917 \\
(0.0147)\end{array}$ \\
\hline$\epsilon_{s t} \times$ listed & $\begin{array}{l}-0.0318 \\
(0.0283)\end{array}$ & $\begin{array}{l}-0.0167 \\
(0.0274)\end{array}$ & $\begin{array}{l}-0.0164 \\
(0.0276)\end{array}$ & $\begin{array}{l}-0.0248 \\
(0.0223)\end{array}$ & $\begin{array}{l}-0.0192 \\
(0.0213)\end{array}$ & $\begin{array}{l}-0.0205 \\
(0.0215)\end{array}$ \\
\hline$\epsilon_{s t} \times$ corp. group & & & $\begin{array}{l}-0.00615 \\
(0.00382)\end{array}$ & & & $\begin{array}{l}0.000496 \\
(0.00435)\end{array}$ \\
\hline$\epsilon_{s t} \times$ metro & & & $\begin{array}{l}0.00944^{* *} \\
(0.00424)\end{array}$ & & & $\begin{array}{l}0.00406 \\
(0.00421)\end{array}$ \\
\hline $\ln a g e_{i t}$ & $\begin{array}{l}0.0618^{* * *} \\
(0.00225)\end{array}$ & $\begin{array}{l}0.0260 * * * \\
(0.00271)\end{array}$ & $\begin{array}{l}0.0264^{* * *} \\
(0.00272)\end{array}$ & $\begin{array}{l}0.0506^{* * *} \\
(0.00249)\end{array}$ & $\begin{array}{l}0.00745^{* *} \\
(0.00323)\end{array}$ & $\begin{array}{c}0.00762^{* *} \\
(0.00323)\end{array}$ \\
\hline Year FE & yes & yes & yes & yes & yes & yes \\
\hline Firm FE & yes & yes & yes & yes & yes & yes \\
\hline Year FE x family firm & no & yes & yes & no & yes & yes \\
\hline Year FE x ln age & no & yes & yes & no & yes & yes \\
\hline Year FE x SOE & no & yes & yes & no & yes & yes \\
\hline Year FE x listed & no & yes & yes & no & yes & yes \\
\hline Year FE x corp. group & no & no & yes & no & no & yes \\
\hline Year FE x metro & no & no & yes & no & no & yes \\
\hline Observations & 444,266 & 444,266 & 444,266 & 318,798 & 318,798 & 318,798 \\
\hline R-squared & 0.062 & 0.068 & 0.070 & 0.048 & 0.053 & 0.055 \\
\hline Number of firms & 100,620 & 100,620 & 100,620 & 80,887 & 80,887 & 80,887 \\
\hline
\end{tabular}

Dependent variable is ln employment ${ }_{i t}$. Robust standard errors in parentheses.

${ }^{* * *} \mathrm{p}<0.01,{ }^{* *} \mathrm{p}<0.05,{ }^{*} \mathrm{p}<0.1$ 
Table 8: Firm level sales GMM regression

\begin{tabular}{lll}
\hline Variable & \multicolumn{2}{c}{ Estimate } \\
\hline ln Sales at $t-1$ & 0.8680 & $(0.0859)$ \\
ln Age & -0.1542 & $(0.0229)$ \\
Metro & -0.0208 & $(0.0310)$ \\
Corp. group & -0.0190 & $(0.0069)$ \\
Listed & 0.1265 & $(0.1661)$ \\
Year FE & 3227.25 & {$[0.0000]$} \\
Industry FE & 59.88 & {$[0.0361]$} \\
& & \\
Hansen J-test & 22.08 & {$[0.002]$} \\
AR(1) test & -10.98 & {$[0.000]$} \\
AR(2) test & 6.33 & {$[0.000]$} \\
AR(3) test & -2.09 & {$[0.037]$} \\
AR(4) test & 1.71 & {$[0.087]$} \\
AR(5) test & -1.03 & {$[0.302]$} \\
AR(6) test & -0.63 & {$[0.528]$} \\
AR(7) test & 1.05 & {$[0.292]$} \\
& & \\
Observations & 331,910 & \\
Number of firms & 70,714 & \\
\hline
\end{tabular}

Dependent variable is the logarithm of sales at time $t$. Estimated by the firstdifferenced GMM, using robust standard errors. Instruments are discussed in the text. For year and industry dummies the joint F- statistic is reported. Standard errors in parentheses. P-values in brackets.
Table 9: Firm level value added GMM regression

\begin{tabular}{lll}
\hline Variable & \multicolumn{2}{c}{ Estimate } \\
\hline ln Value added at $t-1$ & 0.8880 & $(0.2717)$ \\
ln Age & -0.1864 & $(0.0278)$ \\
Metro & -0.0535 & $(0.0435)$ \\
Corp. group & -0.0160 & $(0.0085)$ \\
Listed & 0.0868 & $(0.1977)$ \\
Year FE & 752.79 & {$[0.0000]$} \\
Industry FE & 32.53 & {$[0.8530]$} \\
& & \\
Hansen J-test & 4.72 & {$[0.094]$} \\
AR $(1)$ test & 4.18 & {$[0.000]$} \\
AR $(2)$ test & 3.14 & {$[0.002]$} \\
AR(3) test & 0.40 & {$[0.693]$} \\
AR(4) test & 0.86 & {$[0.392]$} \\
AR(5) test & 0.83 & {$[0.407]$} \\
AR $(6)$ test & 0.64 & {$[0.524]$} \\
AR(7) test & 0.51 & {$[0.608]$} \\
& & \\
Observations & 227,523 & \\
Number of firms & 56,680 & \\
\hline
\end{tabular}

Dependent variable is the logarithm of value added at time $t$. Estimated by the firstdifferenced GMM, using robust standard errors. Instruments are discussed in the text. For year and industry dummies the joint F- statistic is reported. Standard errors in parentheses. P-values in brackets. 
Table 10: Employment GMM regression

\begin{tabular}{|c|c|c|}
\hline Variable & \multicolumn{2}{|c|}{ Estimate } \\
\hline ln Employment at $t-1$ & 0.9738 & $(0.0266)$ \\
\hline ln Age & -0.0310 & $(0.0031)$ \\
\hline Metro & -0.0345 & $(0.0131)$ \\
\hline Corp. group & -0.0003 & $(0.0022)$ \\
\hline Listed & -0.0182 & $(0.0210)$ \\
\hline Year FE & 2557.27 & {$[0.0000]$} \\
\hline Industry FE & 71.45 & {$[0.0031]$} \\
\hline Hansen J-test & 4.64 & {$[0.200]$} \\
\hline $\mathrm{AR}(1)$ test & -38.91 & {$[0.000]$} \\
\hline $\operatorname{AR}(2)$ test & 16.80 & {$[0.000]$} \\
\hline $\mathrm{AR}(3)$ test & 0.77 & {$[0.440]$} \\
\hline $\operatorname{AR}(4)$ test & 0.05 & {$[0.962]$} \\
\hline $\mathrm{AR}(5)$ test & -0.94 & {$[0.347]$} \\
\hline $\operatorname{AR}(6)$ test & 1.02 & {$[0.309]$} \\
\hline $\operatorname{AR}(7)$ test & 0.34 & {$[0.733]$} \\
\hline Observations & \\
\hline Number of firms & \multicolumn{2}{|l|}{75,933} \\
\hline \multicolumn{3}{|c|}{$\begin{array}{l}\text { Dependent variable is the logarithm of } \\
\text { employment at time } t \text {. Estimated by the first- } \\
\text { differenced GMM, using robust standard errors } \\
\text { Instruments are discussed in the text. For year } \\
\text { and industry dummies the joint F- statisti } \\
\text { is reported. Standard errors in parentheses } \\
\text { P-values in brackets. }\end{array}$} \\
\hline
\end{tabular}

Table 11: Sensitivity of employment to temporary firm level shocks

\begin{tabular}{|c|c|c|c|c|c|c|}
\hline & \multicolumn{3}{|c|}{ Sales } & \multicolumn{3}{|c|}{ Value added } \\
\hline & $k=1$ & $k=2$ & $k=3$ & $k=1$ & $k=2$ & $k=3$ \\
\hline$\Delta \epsilon_{i t}$ & $\begin{array}{l}0.00161 \\
(0.00393)\end{array}$ & $\begin{array}{l}-7.56 \mathrm{e}-05 \\
(0.00387)\end{array}$ & $\begin{array}{l}-0.000685 \\
(0.00385)\end{array}$ & $\begin{array}{l}-0.000534 \\
(0.00345)\end{array}$ & $\begin{array}{l}-0.000825 \\
(0.00345)\end{array}$ & $\begin{array}{c}-0.000741 \\
(0.00343)\end{array}$ \\
\hline$\Delta \epsilon_{i t} \times$ family firm & $\begin{array}{l}-0.0310^{* * *} \\
(0.00675)\end{array}$ & $\begin{array}{l}-0.0298^{* * *} \\
(0.00663)\end{array}$ & $\begin{array}{l}-0.0269^{* * *} \\
(0.00652)\end{array}$ & $\begin{array}{l}-0.0278^{* * *} \\
(0.00617)\end{array}$ & $\begin{array}{l}-0.0290^{* * *} \\
(0.00615)\end{array}$ & $\begin{array}{l}-0.0301^{* * *} \\
(0.00608)\end{array}$ \\
\hline $\begin{array}{l}\text { Observations } \\
\text { Hansen } J \text {-test }\end{array}$ & $\begin{array}{l}256,758 \\
\text { exactly } \\
\text { identified }\end{array}$ & $\begin{array}{l}256,758 \\
10.362 \\
{[0.0056]}\end{array}$ & $\begin{array}{l}256,758 \\
19.162 \\
{[0.0007]}\end{array}$ & $\begin{array}{l}168,111 \\
\text { exactly } \\
\text { identified }\end{array}$ & $\begin{array}{l}168,111 \\
7.760 \\
{[0.0206]}\end{array}$ & $\begin{array}{l}168,111 \\
9.014 \\
{[0.0607]}\end{array}$ \\
\hline
\end{tabular}

The dependent variable is $\Delta \omega_{i t}$. Robust standard errors in parentheses. P-values in brackets. Instruments are defined as $\left(\Delta \epsilon_{i, t+1}\right)^{k}$ for $k=1,2,3$.

$* * * \mathrm{p}<0.01,{ }^{* *} \mathrm{p}<0.05, * \mathrm{p}<0.1$ 
Table 12: Sensitivity of employment to permanent firm level shocks

\begin{tabular}{lllllll}
\hline & \multicolumn{3}{c}{ Sales } & \multicolumn{3}{c}{ Value added } \\
& $k=1$ & $k=2$ & $k=3$ & $k=1$ & $k=2$ & $k=3$ \\
\hline \multirow{3}{*}{$\Delta \epsilon_{i t}$} & & & & & & \\
\multirow{4}{*}{$\Delta \epsilon_{i t} \times$ family firm } & $0.0482^{* * *}$ & $0.0410^{* * *}$ & $0.0494^{* * *}$ & $0.0223^{* * *}$ & $0.0213^{* * *}$ & $0.0198^{* * *}$ \\
& $(0.00435)$ & $(0.00437)$ & $(0.00395)$ & $(0.00336)$ & $(0.00335)$ & $(0.00331)$ \\
& $(0.00696)$ & 0.00647 & $-0.0201^{* * *}$ & 0.00324 & 0.00658 & 0.00211 \\
Observations & $(0.00759)$ & $(0.00580)$ & $(0.00591)$ & $(0.00588)$ & $(0.00555)$ \\
Hansen $J$-test & 122,371 & 122,371 & 122,371 & 62,927 & 62,927 & 62,927 \\
& 345.722 & 420.257 & 529.316 & 168.962 & 205.701 & 286.278 \\
& {$[0.0000]$} & {$[0.0000]$} & {$[0.0000]$} & {$[0.0000]$} & {$[0.0000]$} & {$[0.0000]$} \\
\hline
\end{tabular}

The dependent variable is $\Delta \omega_{i t}$. Robust standard errors in parentheses. P-values in brackets. Instruments are defined as $\left(\sum_{\tau=-2}^{2} \Delta \epsilon_{i, t+\tau}\right)^{k}$ for $k=1,2,3$.

$* * * \mathrm{p}<0.01,{ }^{* *} \mathrm{p}<0.05, * \mathrm{p}<0.1$ 


\section{B Figures}

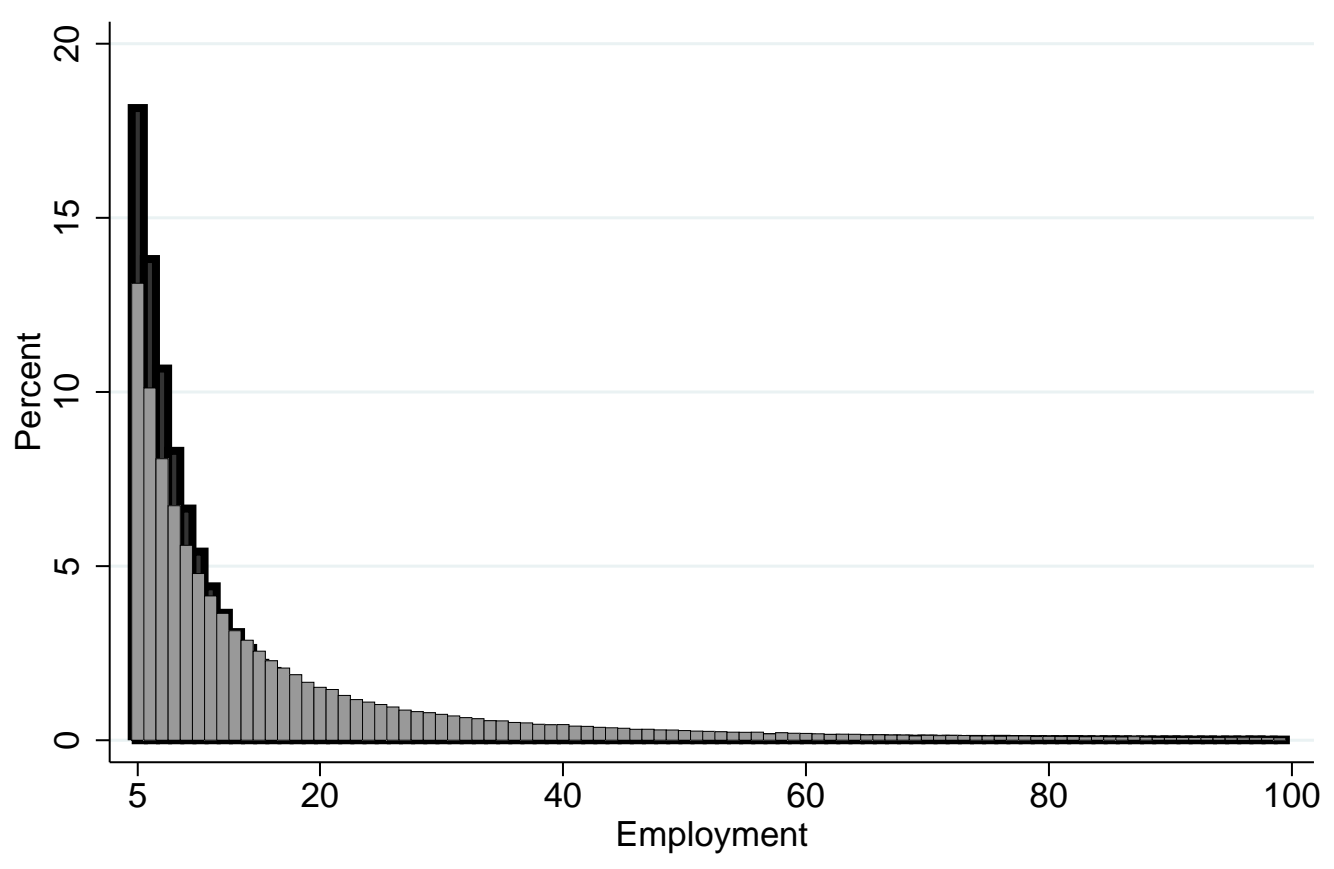

Family firms $\square$ Non-family firms

Figure 1: Distribution of firm size, 1997-2009. 


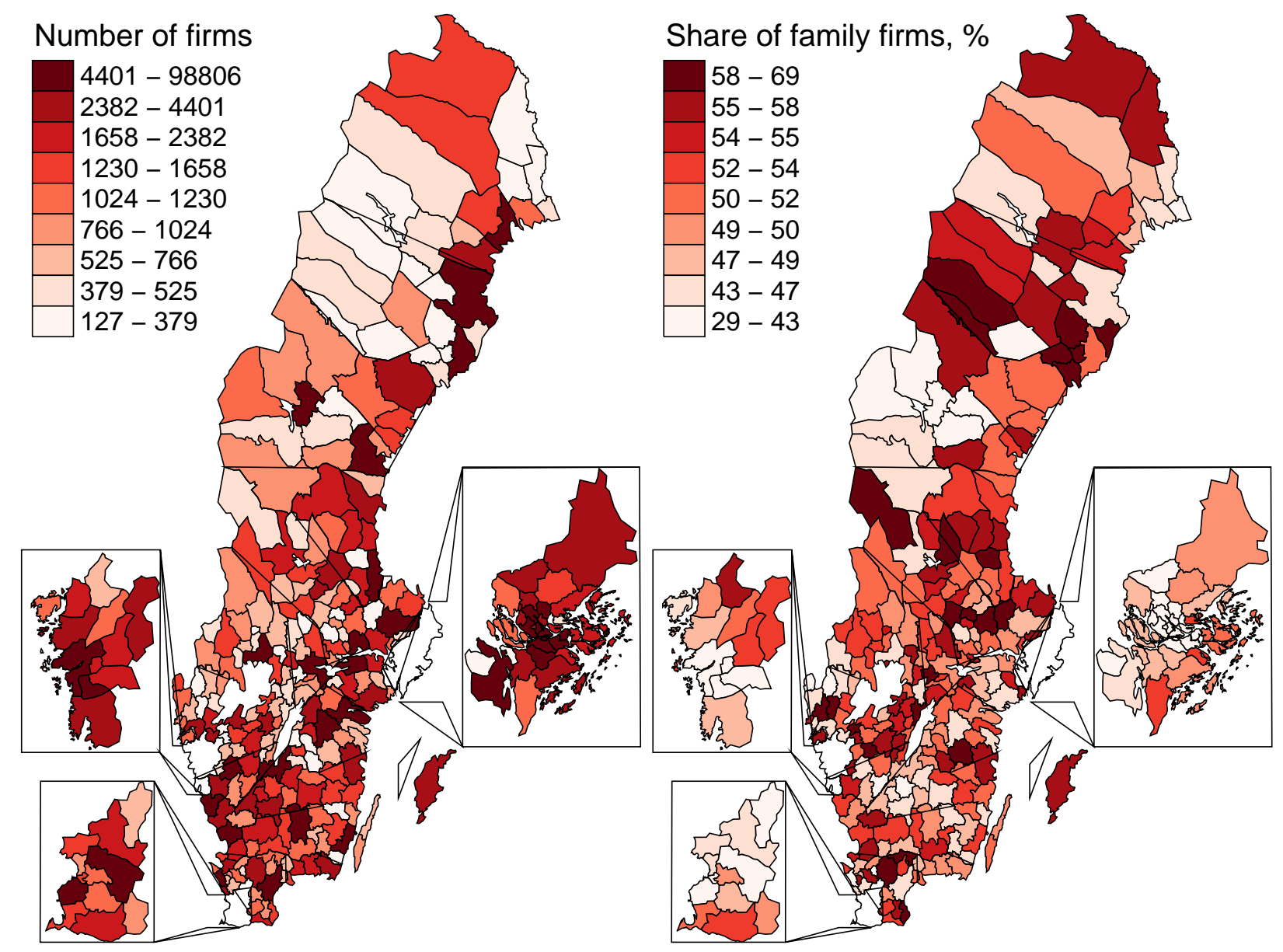

Figure 2: Geographical distribution over municipalities, 1997-2009. The enlarged areas correspond to the greater metropolitan areas of Stockholm, Gothenburg, and Malmö. 


\section{Appendix}

Table A1: Number of firms, year by year

\begin{tabular}{clll}
\hline Year & Non-family & Family & Total \\
\hline & & & \\
1997 & 31,284 & 19,994 & 51,278 \\
1998 & 32,189 & 20,932 & 53,121 \\
1999 & 32,793 & 21,764 & 54,557 \\
2000 & 33,646 & 22,490 & 56,136 \\
2001 & 32,983 & 23,195 & 56,178 \\
2002 & 30,851 & 25,636 & 56,487 \\
2003 & 29,634 & 26,746 & 56,380 \\
2004 & 31,026 & 26,993 & 58,019 \\
2005 & 31,755 & 27,795 & 59,550 \\
2006 & 33,186 & 28,228 & 61,414 \\
2007 & 34,727 & 29,421 & 64,148 \\
2008 & 35,832 & 29,873 & 65,705 \\
2009 & 35,474 & 29,272 & 64,746 \\
& & & \\
Total & 425,380 & 332,339 & 757,719 \\
\hline
\end{tabular}


Table A2: Firms within each industry

\begin{tabular}{|c|c|c|c|c|}
\hline NACE & Industry & $\begin{array}{c}\text { Share of } \\
\text { non-family firms }\end{array}$ & $\begin{array}{c}\text { Share of } \\
\text { family firms }\end{array}$ & $\begin{array}{l}\text { Total number } \\
\text { of firms }\end{array}$ \\
\hline 15 & manufacture of food products and beverages & 56 & 44 & 12,081 \\
\hline 17 & manufacture of textiles & 52 & 48 & 2,948 \\
\hline 18 & manufacture of wearing apparel & 57 & 43 & 923 \\
\hline 19 & tanning and dressing of leather & 52 & 48 & 516 \\
\hline 20 & manufacture of wood and of products of wood and cork & 56 & 44 & 12,658 \\
\hline 21 & manufacture of paper and paper products & 77 & 23 & 2,392 \\
\hline 22 & publishing, printing and reproduction of recorded media & 67 & 33 & 16,660 \\
\hline 24 & manufacture of chemicals and chemical products & 76 & 24 & 3,536 \\
\hline 25 & manufacture of rubber and plastics products & 62 & 38 & 7,585 \\
\hline 26 & manufacture of other non-metallic mineral products & 65 & 35 & 3,574 \\
\hline 27 & manufacture of basic metals & 75 & 25 & 2,271 \\
\hline 28 & manufacture of fabricated metal products & 51 & 49 & 36,063 \\
\hline 29 & manufacture of machinery and equipment n.e.c.* & 61 & 39 & 18,963 \\
\hline 30 & manufacture of office, accounting and computing machinery & 61 & 39 & 958 \\
\hline 31 & manufacture of electrical machinery and apparatus n.e.c. & 60 & 40 & 5,315 \\
\hline 32 & manufacture of radio, television and communication equipment & 63 & 37 & 2,099 \\
\hline 33 & manufacture of medical, precision and optical instruments, etc. & 68 & 32 & 5,143 \\
\hline 34 & manufacture of motor vehicles, trailers and semi-trailers & 64 & 36 & 3,669 \\
\hline 35 & manufacture of other transport equipment & 61 & 39 & 2,725 \\
\hline 36 & manufacture of furniture; manufacturing n.e.c. & 56 & 44 & 7,770 \\
\hline 37 & recycling & 58 & 42 & 1,031 \\
\hline 45 & construction & 43 & 57 & 98,285 \\
\hline 50 & sale, maintenance and repair of motor vehicles and motorcycles & 45 & 55 & 36,433 \\
\hline 51 & wholesale trade and commission trade & 65 & 35 & 88,610 \\
\hline 52 & retail trade, except of motor vehicles and motorcycles & 46 & 54 & 88,835 \\
\hline 55 & hotels and restaurants & 59 & 41 & 46810 \\
\hline 60 & land transport; transport via pipelines & 43 & 57 & 42,664 \\
\hline 61 & water transport & 75 & 25 & 1,582 \\
\hline 62 & air transport & 75 & 25 & 485 \\
\hline 63 & supporting and auxiliary transport activities & 72 & 28 & 11,280 \\
\hline 64 & post and telecommunications & 77 & 23 & 1,717 \\
\hline 65 & financial intermediation, except insurance and pension funding & 89 & 11 & 1,959 \\
\hline 67 & activities auxiliary to financial intermediation & 79 & 21 & 3,894 \\
\hline 70 & real estate activities & 62 & 38 & 13,945 \\
\hline 71 & renting of machinery and equipment & 57 & 43 & 4,989 \\
\hline 72 & computer and related activities & 77 & 23 & 25,737 \\
\hline 73 & research and development & 84 & 16 & 2,731 \\
\hline 74 & other business activities & 63 & 37 & 90,565 \\
\hline 80 & education & 55 & 45 & 10,019 \\
\hline 85 & health and social work & 56 & 44 & 18,802 \\
\hline 90 & sewage and refuse disposal, sanitation and similar activities & 61 & 39 & 1,794 \\
\hline 92 & recreational, cultural and sporting activities & 68 & 32 & 10,877 \\
\hline 93 & other service activities & 44 & 56 & 6,826 \\
\hline Total & & 56 & 44 & 757,719 \\
\hline
\end{tabular}


Table A3: The three greater metropolitan areas, divided into municipalities

\begin{tabular}{lll}
\hline Stockholm & Göteborg & Malmö \\
\hline Botkyrka & Ale & Burlöv \\
Danderyd & Alingsås & Eslöv \\
Ekerö & Göteborg & Höör \\
Haninge & Härryda & Kävlinge \\
Huddinge & Kungsbacka & Lomma \\
Järfälla & Kungälv & Lund \\
Lidingö & Lerum & Malmö \\
Nacka & Lilla Edet & Skurup \\
Norrtälje & Mölndal & Staffanstorp \\
Nykvarn & Partille & Svedala \\
Nynäshamn & Stenungsund & Trelleborg \\
Salem & Tjörn & Vellinge \\
Sigtuna & Öckerö & \\
Sollentuna & & \\
Solna & & \\
Stockholm & & \\
Sundbyberg & & \\
Södertälje & & \\
Tyresö & & \\
Täby & & \\
Upplands & & \\
Upplands-Bro & & \\
Vallentuna & & \\
Vaxholm & & \\
Värmdö & & \\
Österåker & & \\
\hline
\end{tabular}

Note: The three greater metropolitan areas are defined by Statistics Sweden. They are also referred to as: Stor-Stockholm, StorGöteborg and Stor-Malmö (Stor being the Swedish word for great). 
Table A4: Firm level sales GMM regression using lags 7 and earlier

\begin{tabular}{lll}
\hline Variable & \multicolumn{2}{c}{ Estimate } \\
\hline & & \\
ln Sales at $t-1$ & 2.4030 & $(0.3540)$ \\
ln Age & -0.5410 & $(0.0927)$ \\
Metro & -0.0765 & $(0.0580)$ \\
Corp. group & -0.0568 & $(0.0148)$ \\
Listed & 0.0723 & $(0.3111)$ \\
Year FE & 720.09 & {$[0.0000]$} \\
Industry FE & 38.19 & {$[0.6390]$} \\
& & \\
Hansen J-test & 5.31 & {$[0.380]$} \\
AR(1) test & -6.91 & {$[0.000]$} \\
AR(2) test & 4.93 & {$[0.000]$} \\
AR(3) test & -1.80 & {$[0.073]$} \\
AR(4) test & 1.95 & {$[0.051]$} \\
AR(5) test & -0.36 & {$[0.720]$} \\
AR(6) test & -0.06 & {$[0.951]$} \\
AR(7) test & 1.02 & {$[0.305]$} \\
& & \\
Observations & 331,910 & \\
Number of firms & 70,714 & \\
\hline
\end{tabular}

Dependent variable is the logarithm of sales at time $t$. Estimated by the first-differenced GMM, using robust standard errors. For year and industry dummies the joint F- statistic is reported. Standard errors in parentheses. $\mathrm{P}$-values in brackets. Instrumented with sales at $t-7$ and earlier. The lags 7-12 are collapsed so that there are one instrument for each variable and lag distance, rather than for each time period, variable and lag distance. 
Table A5: Sensitivity of employment to firm level sales shocks using alternate residuals

\begin{tabular}{lllllll}
\hline & \multicolumn{3}{c}{ Temporary } & \multicolumn{3}{c}{ Permanent } \\
& $k=1$ & $k=2$ & $k=3$ & $k=1$ & $k=2$ & $k=3$ \\
\hline \multirow{3}{*}{$\Delta \epsilon_{i t}$} & $0.0220^{* * *}$ & $0.0197^{* * *}$ & $0.0172^{* * *}$ & $0.0270^{* * *}$ & $0.0287^{* * *}$ & $0.0276^{* * *}$ \\
$\Delta \epsilon_{i t} \times$ family firm & $(0.00254)$ & $(0.00243)$ & $(0.00231)$ & $(0.00275)$ & $(0.00276)$ & $(0.00231)$ \\
& $-0.0132^{* * *}$ & $-0.0103^{* * *}$ & $-0.00929^{* * *}$ & 0.00602 & -0.00318 & $-0.00856^{* * *}$ \\
& $(0.00406)$ & $(0.00376)$ & $(0.00343)$ & $(0.00421)$ & $(0.00429)$ & $(0.00323)$ \\
Observations & & & & & & \\
Hansen $J$-test & 256,758 & 256,758 & 256,758 & 122,371 & 122,371 & 122,371 \\
& exactly & 13.639 & 38.937 & 589.219 & 694.608 & 826.443 \\
& identified & {$[0.0011]$} & {$[0.0000]$} & {$[0.0000]$} & {$[0.0000]$} & {$[0.0000]$} \\
\hline
\end{tabular}

The dependent variable is $\Delta \omega_{i t}$. Robust standard errors in parentheses. P-values in brackets. Instruments for the permanent shock estimations are defined as $\left(\sum_{\tau=-2}^{2} \Delta \epsilon_{i, t+\tau}\right)^{k}$ for $k=1,2,3$. Instruments for the temporary shock estimations are defined as $\left(\Delta \epsilon_{i, t+1}\right)^{k}$ for $k=1,2,3 . \Delta \epsilon_{i t}$ is the residual from the estimation in Table A4.

*** $\mathrm{p}<0.01,{ }^{* *} \mathrm{p}<0.05,{ }^{*} \mathrm{p}<0.1$

Table A6: Firm level sales GMM regression using lags 3 and earlier as instruments

\begin{tabular}{|c|c|c|}
\hline \multirow{2}{*}{$\begin{array}{l}\text { Variable } \\
\text { ln Sales at } t-1\end{array}$} & \multicolumn{2}{|c|}{ Estimate } \\
\hline & 0.4675 & $(0.0243)$ \\
\hline ln Age & -0.0345 & $(0.0066)$ \\
\hline Metro & -0.0073 & $(0.0260)$ \\
\hline Corp. group & -0.0084 & $(0.0054)$ \\
\hline Listed & 0.1426 & $(0.1341)$ \\
\hline Year FE & 4421.86 & {$[0.0000]$} \\
\hline Industry FE & 77.96 & {$[0.0006]$} \\
\hline Hansen J-test & 356.97 & {$[0.000]$} \\
\hline $\mathrm{AR}(1)$ test & -17.98 & {$[0.000]$} \\
\hline $\mathrm{AR}(2)$ test & 6.25 & {$[0.000]$} \\
\hline $\operatorname{AR}(3)$ test & -2.27 & {$[0.023]$} \\
\hline $\operatorname{AR}(4)$ test & 1.66 & {$[0.097]$} \\
\hline $\mathrm{AR}(5)$ test & -0.99 & {$[0.323]$} \\
\hline $\mathrm{AR}(6)$ test & -0.30 & {$[0.766]$} \\
\hline $\operatorname{AR}(7)$ test & 1.51 & {$[0.131]$} \\
\hline Observations & \\
\hline \multicolumn{2}{|c|}{ Number of firms $\quad 70,714$} & \\
\hline \multicolumn{3}{|c|}{$\begin{array}{l}\text { Dependent variable is the logarithm } \\
\text { of sales at time } t \text {. Estimated by the } \\
\text { first-differenced GMM, using robust } \\
\text { standard errors. For year and industry } \\
\text { dummies the joint F- statistic is re- } \\
\text { ported. Standard errors in parentheses. } \\
\text { P-values in brackets. Instrumented with } \\
\text { sales at } t-3 \text { and earlier. }\end{array}$} \\
\hline
\end{tabular}

Table A7: Firm level value added GMM regression using lags 3 and earlier as instruments

\begin{tabular}{|c|c|c|}
\hline Variable & \multicolumn{2}{|c|}{ Estimate } \\
\hline $\ln$ Value added at $t-1$ & 0.3412 & $(0.0286)$ \\
\hline ln Age & -0.0246 & $(0.0087)$ \\
\hline Metro & -0.0340 & $(0.0318)$ \\
\hline Corp. group & -0.0070 & $(0.0055)$ \\
\hline Listed & 0.0918 & $(0.1544)$ \\
\hline Year FE & 1309.19 & {$[0.0000]$} \\
\hline Industry FE & 42.74 & {$[0.4394]$} \\
\hline Hansen J-test & 106.38 & {$[0.000]$} \\
\hline $\mathrm{AR}(1)$ test & -18.62 & {$[0.000]$} \\
\hline $\mathrm{AR}(2)$ test & 8.75 & {$[0.000]$} \\
\hline $\mathrm{AR}(3)$ test & -0.51 & $0.610]$ \\
\hline $\mathrm{AR}(4)$ test & 1.35 & {$[0.176]$} \\
\hline $\mathrm{AR}(5)$ test & -0.52 & {$[0.606]$} \\
\hline $\mathrm{AR}(6)$ test & -0.83 & {$[0.406]$} \\
\hline $\operatorname{AR}(7)$ test & 1.25 & {$[0.212]$} \\
\hline Observations & 227,523 & \\
\hline Number of firms & 56,680 & \\
\hline $\begin{array}{l}\text { Dependent variable is } \\
\text { value added at time } t \text {. } \\
\text { first-differenced GMM, } \\
\text { dard errors. For year an } \\
\text { the joint F- statistic is } \\
\text { errors in parentheses. P-v } \\
\text { strumented with value add }\end{array}$ & $\begin{array}{l}\text { the lo } \\
\text { Estim } \\
\text { ising r } \\
\text { indus }\end{array}$ & $\begin{array}{l}\text { rithm of } \\
\text { ust by the } \\
\text { dummies } \\
\text { Standard } \\
\text { ackets. In- } \\
\text { nd earlier. }\end{array}$ \\
\hline
\end{tabular}


Table A8: Firm level employment GMM regression using lags 3 and earlier as instruments

\begin{tabular}{|c|c|c|}
\hline Variable & \multicolumn{2}{|c|}{ Estimate } \\
\hline $\ln$ Employment at $t-1$ & 0.8350 & $(0.0183)$ \\
\hline $\ln$ Age & -0.0206 & $(0.0026)$ \\
\hline Metro & -0.0313 & $(0.0124)$ \\
\hline Corp. group & 0.0014 & $(0.0020)$ \\
\hline Listed & -0.0067 & $(0.0193)$ \\
\hline Year FE & 2823.72 & {$[0.0000]$} \\
\hline Industry FE & 74.15 & {$[0.0016]$} \\
\hline Hansen J-test & 206.41 & {$[0.000]$} \\
\hline $\mathrm{AR}(1)$ test & -48.10 & {$[0.000]$} \\
\hline $\mathrm{AR}(2)$ test & 17.41 & {$[0.000]$} \\
\hline $\mathrm{AR}(3)$ test & 0.72 & {$[0.470]$} \\
\hline $\mathrm{AR}(4)$ test & 0.07 & {$[0.945]$} \\
\hline $\mathrm{AR}(5)$ test & -0.84 & {$[0.404]$} \\
\hline $\mathrm{AR}(6)$ test & 1.03 & {$[0.303]$} \\
\hline $\mathrm{AR}(7)$ test & 0.36 & {$[0.716]$} \\
\hline Observations & 371,896 & \\
\hline Number of firms & 75,933 & \\
\hline $\begin{array}{l}\text { Dependent variable is } \\
\text { employment at time } t \text {. } \\
\text { first-differenced GMM, u } \\
\text { errors. For year and in } \\
\text { joint F- statistic is repor } \\
\text { in parentheses. P-values } \\
\text { mented with employment }\end{array}$ & $\begin{array}{l}\text { the lo } \\
\text { Estima } \\
\text { ng robu } \\
\text { lustry d } \\
\text { d. Star }\end{array}$ & $\begin{array}{l}\text { arithm o } \\
\text { d by the } \\
\text { standare } \\
\text { nmies the } \\
\text { lard error } \\
\text { s. Instru }\end{array}$ \\
\hline
\end{tabular}

Table A9: Sensitivity of employment to permanent firm level shocks, using residuals from Table A6,A7, and A8.

\begin{tabular}{lllllll}
\hline & \multicolumn{3}{c}{ Sales } & & \multicolumn{3}{c}{ Value added } \\
& $k=1$ & $k=2$ & $k=3$ & $k=1$ & $k=2$ & $k=3$ \\
\hline \multirow{3}{*}{$\Delta \epsilon_{i t}$} & & & & & & \\
\multirow{4}{*}{$\Delta \epsilon_{i t} \times$ family firm } & $-0.0518^{* * *}$ & $0.0395^{* * *}$ & $0.0472^{* * *}$ & $0.0201^{* * *}$ & $0.0212^{* * *}$ & $0.0180^{* * *}$ \\
& $(0.00530)$ & $(0.00555)$ & $(0.00481)$ & $(0.00451)$ & $(0.00448)$ & $(0.00432)$ \\
& $(0.00845)$ & 0.00700 & $-0.0328^{* * *}$ & 0.000803 & 0.00472 & -0.00319 \\
Observations & $10.00969)$ & $(0.00715)$ & $(0.00816)$ & $(0.00807)$ & $(0.00769)$ \\
Hansen $J$-test & 122,371 & 122,371 & 122,371 & 62,927 & 62,927 & 62,927 \\
& 645.752 & 778.402 & 897.806 & 366.574 & 417.337 & 502.824 \\
& {$[0.0000]$} & {$[0.0000]$} & {$[0.0000]$} & {$[0.0000]$} & {$[0.0000]$} & {$[0.0000]$} \\
\hline
\end{tabular}

The dependent variable is $\Delta \omega_{i t}$. Robust standard errors in parentheses. P-values in brackets. Instruments are defined as $\left(\sum_{\tau=-2}^{2} \Delta \epsilon_{i, t+\tau}\right)^{k}$ for $k=1,2,3$. The residuals $\Delta \omega_{i t}$ and $\Delta \epsilon_{i t}$ are from equations where sales and value added where instrumented with lags in period $t-3$ and earlier, and employment was instrumented with lags in period $t-4$ and earlier.

$* * * \mathrm{p}<0.01,{ }^{* *} \mathrm{p}<0.05,{ }^{*} \mathrm{p}<0.1$ 
Table A10: Sensitivity of employment to temporary firm level shocks, using residuals from Table A6,A7, and A8

\begin{tabular}{|c|c|c|c|c|c|c|}
\hline & \multicolumn{3}{|c|}{ Sales } & \multicolumn{3}{|c|}{ Value added } \\
\hline & $k=1$ & $k=2$ & $k=3$ & $k=1$ & $k=2$ & $k=3$ \\
\hline$\Delta \epsilon_{i t}$ & $\begin{array}{l}-0.0239 * * * \\
(0.00546)\end{array}$ & $\begin{array}{l}-0.0267^{* * *} \\
(0.00530)\end{array}$ & $\begin{array}{l}-0.0260 * * * \\
(0.00522)\end{array}$ & $\begin{array}{l}-0.0301^{* * *} \\
(0.00530)\end{array}$ & $\begin{array}{l}-0.0269^{* * *} \\
(0.00515)\end{array}$ & $\begin{array}{l}-0.0277^{* * *} \\
(0.00504)\end{array}$ \\
\hline$\Delta \epsilon_{i t} \times$ family firm & $\begin{array}{l}-0.0438^{* * *} \\
(0.00959)\end{array}$ & $\begin{array}{l}-0.0439^{* * *} \\
(0.00921)\end{array}$ & $\begin{array}{l}-0.0469^{* * *} \\
(0.00918)\end{array}$ & $\begin{array}{l}-0.0513^{* * *} \\
(0.00972)\end{array}$ & $\begin{array}{l}-0.0604^{* * *} \\
(0.00941)\end{array}$ & $\begin{array}{l}-0.0587^{* * *} \\
(0.00914)\end{array}$ \\
\hline $\begin{array}{l}\text { Observations } \\
\text { Hansen } J \text {-test }\end{array}$ & $\begin{array}{l}256,758 \\
\text { exactly } \\
\text { identified }\end{array}$ & $\begin{array}{l}256,758 \\
36.323 \\
{[0.0000]}\end{array}$ & $\begin{array}{l}256,758 \\
46.272 \\
{[0.0000]}\end{array}$ & $\begin{array}{l}168,111 \\
\text { exactly } \\
\text { identified }\end{array}$ & $\begin{array}{l}168,111 \\
29.908 \\
{[0.0000]}\end{array}$ & $\begin{array}{l}168,111 \\
29.820 \\
{[0.0000]}\end{array}$ \\
\hline
\end{tabular}

The dependent variable is $\Delta \omega_{i t}$. Robust standard errors in parentheses. P-values in brackets. Instruments are defined as $\left(\Delta \epsilon_{i, t+1}\right)^{k}$ for $k=1,2,3$. The residuals $\Delta \omega_{i t}$ and $\Delta \epsilon_{i t}$ are from equations where sales and value added where instrumented with lags in period $t-3$ and earlier, and employment was instrumented with lags in period $t-4$ and earlier.

*** $\mathrm{p}<0.01, * * \mathrm{p}<0.05, * \mathrm{p}<0.1$ 